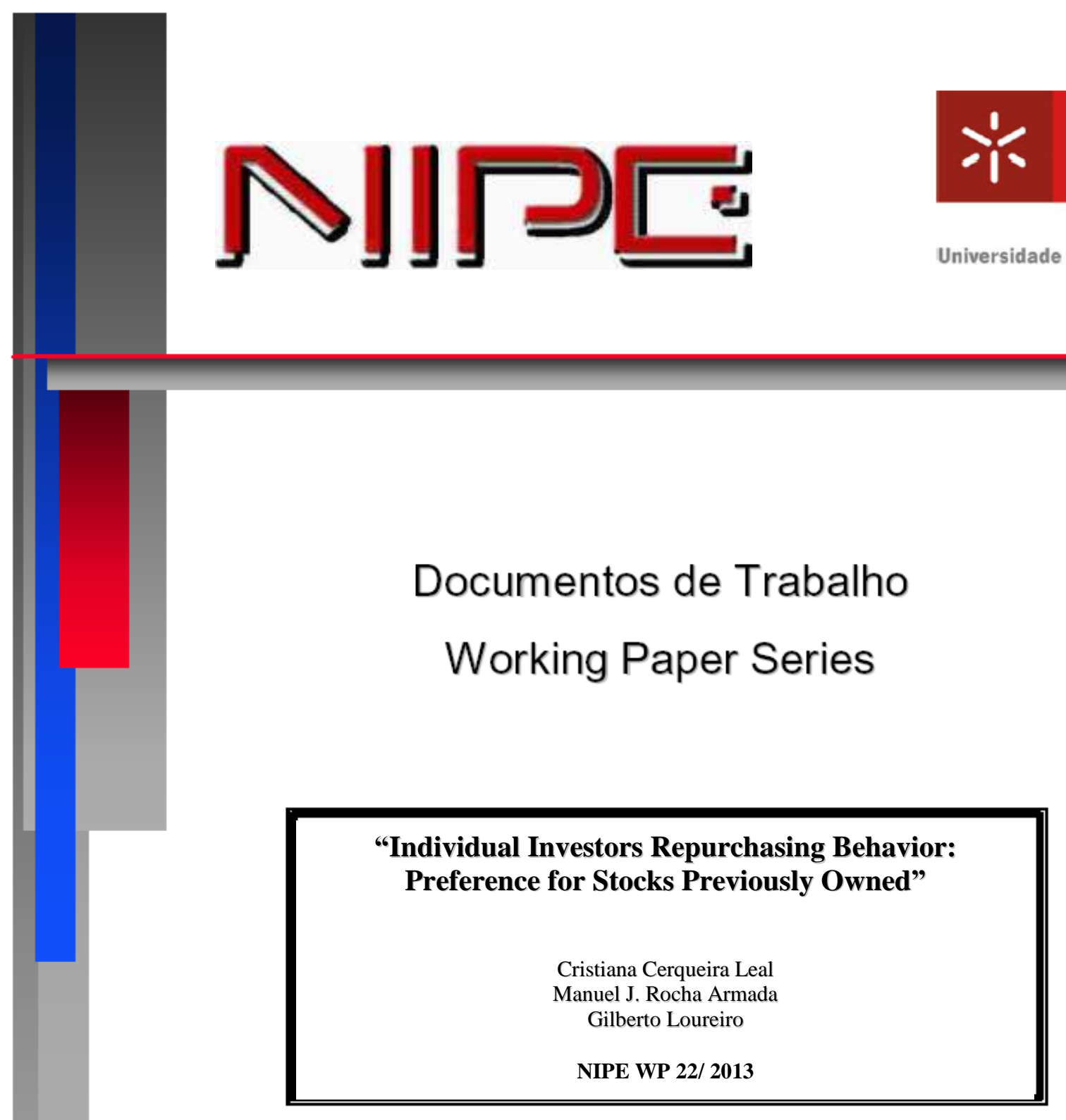

NÚCLEO DE INVESTIGAÇÃO EM POLÍTICAS ECONÓMICAS UNIVERSIDADE DO MINHO 


\section{"Individual Investors Repurchasing Behavior: Preference for Stocks Previously Owned"}

Cristiana Cerqueira Leal

Manuel J. Rocha Armada

Gilberto Loureiro

NIPE ${ }^{*}$ WP 22/ 2013

URL:

http://www.eeg.uminho.pt/economia/nipe
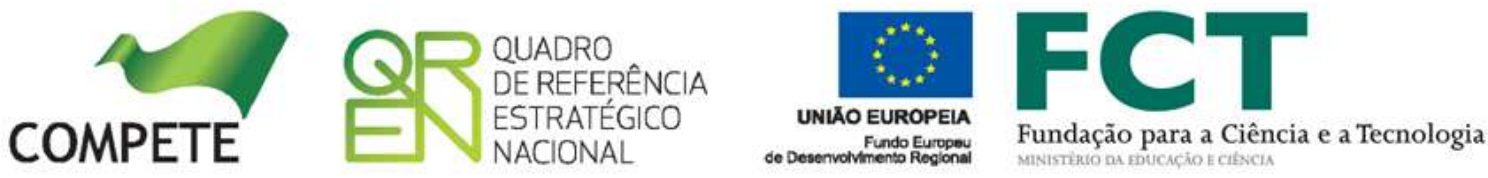


\title{
Individual Investors Repurchasing Behavior: Preference for Stocks Previously Owned
}

\author{
Cristiana Cerqueira Leal \\ NIPE \& School of Economics and Management - University of Minho \\ Campus de Gualtar \\ 4710-057 Braga - Portugal \\ ccerqueira@eeg.uminho.pt \\ Manuel J. Rocha Armada \\ NIPE \& School of Economics and Management - University of Minho \\ Campus de Gualtar \\ 4710-057 Braga - Portugal \\ rarmada@eeg.uminho.pt \\ Gilberto Loureiro \\ NIPE \& School of Economics and Management - University of Minho \\ Campus de Gualtar \\ 4710-057 Braga - Portugal \\ gilberto@eeg.uminho.pt
}

This version: November 2013 


\title{
Individual Investors Repurchasing Behavior: Preference for Stocks Previously Owned
}

\begin{abstract}
In this paper we study the repurchasing behavior of individual investors and identify several characteristics (stock- and investor-specific) that affect the preference for repurchasing stocks previously owned. Using a unique database of 5,128 individual investors trading from August $1^{\text {st }}, 2003$ to July $31^{\text {st }}, 2007$, we find that investors prefer to repurchase stocks that are prior winners and those that dropped in price after being sold, in line with Strahilevitz, Odean and Barber (2011). We also find that the larger the prior gain, or the drop in stock price after the sell, the more likely is the investor to repurchase the same stock. Additionally, we find that (1) local stocks with negative market adjusted performance are more likely to be repurchased, and (2) less active, under-diversified, and poor performance investors are more likely to engage in such behavior. Overall, our results indicate that reference prices, prior stock returns, stock visibility, and investor performance and sophistication are determinants of the repurchasing behavior.
\end{abstract}

JEL classification: G02; G11; G14

Keywords: regret; counterfactuals; portfolio choice; individual investors. 


\section{Introduction}

Given the immense set of investment opportunities, investors need to narrow the amount of possibilities due to time constraints, effort and cognitive limitations. Some clusters catch investors' attention. For instance, stocks that are geographically closer to them (Grinblatt and Keloharju, 2001a; Huberman, 2001; Feng and Seasholes, 2004; Ivkovich and Weisbenner, 2005) or that are more visible in the media (Barber, Odean and Zhu, 2009) catch investors attention, are easily recalled, and consequently, are considered for purchase. We would also expect that investors are more likely to repurchase stocks that they have previously owned both because they can easily recall them and they have learned something about them. However, investors do not want to repurchase those stocks at the same rate. The prior experienced prices act as anchors and affect the wiliness to repurchase. When an investor buys an asset by the first time at some price, he becomes anchored to that price and it determines the future accepted prices, even if they are arbitrary, because individuals seek to be coherent with previous decisions (Ariely, Loewenstein and Prelec, 2003). In the context of repurchasing behavior study, the concept of mental accounting is extended, in line with Arkes, Hirshleifer, Jiang and Lim (2008): even when the security is sold, the account is kept opened and investors continue monitoring prices to implement future decisions. Strahilevitz, Odean and Barber (2011) looking at these particular anchors established the following patterns: (1) preference for repurchasing stocks previously sold for a gain rather than a loss; and (2) preference for repurchasing stocks that have lost rather than gained value subsequent to a prior sale. Weber and Welfens (2011) using an experimental setting applied to 145 students also document the same patterns. Apart from these studies, the topic of repurchasing behavior is much unaddressed in the literature. This paper aims to contribute to the understanding of this phenomenon by analyzing the portfolios of 5,128 individual investors during four years (from August 2003 to July 2007). First, we analyze who is repurchasing, and which stocks are being repurchased, compared to all purchases that occurred in the period. We argue that more unsophisticated investors are more likely to repurchase and geographically closer and more visible stocks are more likely to be repurchased. Secondly, we identify patterns of repurchasing behavior related to past anchors, not only at the aggregated level, as in Strahilevitz, Odean and Barber (2011), but also at the individual level ${ }^{1}$. Third, we focus only on the investors that have repurchases in the data period and test whether the repurchasing behavior is associated with investor and stock characteristics. In general, the literature identifies such characteristics as variables that may increase or attenuate behavioral bias. We use them in multivariate analysis to determine preferences in the repurchasing behavior, which, to the best of our knowledge, has never been done in the context of repurchasing behavior. Demographic and investors' trading-specific variables are accepted in the literature as proxies for investor sophistication, in the sense that they predict the behavioral bias reduction. The literature identifies wealth, experience, financial literacy, occupational status, diversification level and IQ, among others, as sources of investor

\footnotetext{
${ }^{1}$ By aggregated level we mean looking at the all trades together, while by individual level we mean measured by investor and then averaged across investor.
} 
sophistication (e.g., Feng and Seasholes, 2005; Campbell, 2006; Dhar and Zhu, 2006; Calvet, Campbell and Sodini, 2007; 2009a; 2009b; Seru, Shumway and Stoffman, 2010; Korniotis and Kumar, 2011; Linnainmaa, 2011; Grinblatt, Keloharju and Linnainmaa, 2012). Stock characteristics also play a role in explaining trading behavior. For instance, the literature identifies preferences for home and local stocks (e.g., Huberman, 2001; Ivkovich, Sialm and Weisbenner, 2008), or preferences related to previous performance (e.g., Kaniel, Saar and Titman, 2008). We argue that variables related to investor sophistication, such as the experience, diversification and performance also determine the likelihood of repurchasing, as we expect that more unsophisticated investors are more eager to repurchase. We also expect that some stocks are more attractive for repurchasing due to their visibility, captured by size, volume, location (home and Euro zone) and performance.

We find that price anchors, prior stock performance, stock visibility, investor performance, and investor sophistication are determinants of repurchasing behavior. Being a prior winner matters as well as the stock price variation after the sell. Our evidence shows that the repurchasing behavior is positively associated with prior gains on the same stock and negatively related with the stock price variation after the sell. We also find that the purchase of prior winners is more frequent among home visible stocks with negative market adjusted performance, especially when the investor is less active, under-diversified and experienced poorer performance. As for investor demographic characteristics (such as age, gender, marital status and profession), we find no evidence that they are associated with the repurchasing behavior.

Our study offers several contributions. First, to the best of our knowledge, this is the largest study on repurchasing behavior outside the U.S.. Second, we identify preferences on investors repurchasing behavior, measured not only at aggregated level (as Strahilevitz, Odean and Barber, 2011) but also at the individual level. Third, we analyze the impact of numerous variables, including stock characteristics, investor trading characteristics and demographic characteristics, on the investors repurchasing behavior and identify several determinants that help explain this phenomenon.

The remainder of this paper is organized as follows: section 2 reviews the literature and section 3 describes the data. Section 4 tests test whether the repurchasing behavior is concentrated in some stocks or type of investors. Section 5 verifies the existence of patterns in the repurchasing behavior. Section 6 tests investor-specific and stock-specific determinants of the repurchasing behavior. Section 7 concludes. 


\section{Literature review: Individual investors behavior and preferences}

As Massa and Simonov (2005) argue, individual stock picking seems to be mostly affected by the amount of information available. Reliance on familiarity with a stock is an easy and cheap way of acquiring information. A source of information-based familiarity is the ownership of the stock. One can expect that investors have accumulated a significant amount of information (somehow seen as expertise) about the stocks previously owned. Consequently, these stocks become salient in the moment of stock selection. In addition, individual investors often discover naïve patterns in past price movements (De Bondt, 1998). Individual investors over-extrapolate from their personal experience when making investment decisions and random accidents of personal financial history, irrelevant to a rational investor, affect their saving decisions (Choi, Laibson, Madrian and Metrick, 2009). In this framework and based on mental accounting, individuals keep track of the prices they have experienced (buying and selling prices) and it is expected that they extrapolate prices to which they have a particular emotional tie.

\subsection{Repurchasing past winners versus past losers}

Gains and losses lead to opposite sentiments and individuals derive utility from them. As Statman (2011) states, investors want to feel pride when investments bring gains and avoid the regret that comes with losses. Thus, investors act in order to feel the pleasure of a good decision and emphasize it. Simultaneously, they try to avoid the experienced regret of a bad decision and hide it. In this setting, in the context of the repurchasing behavior, investors keep the mental account of stocks previously owned and its reference prices as anchors for future decisions. Then, we can expect that investors prefer to repurchase past winners rather than past losers to emphasize the sources of pleasure and eschewing the sources of experienced regret. Even if, eventually, some future losses occur when repurchasing the stock, investors use mental accounting strategies to integrate those losses in the total gains and keep believing that overall the stock is a winning one, in line with Thaler (1985). Simultaneously, inventors avoid repurchasing their past losers in order to stay away from the sources of experienced regret. When a stock is a loser, it is very difficult to mitigate the disappointment and regret with the prospect that it will recover. If, even so, the investor decides to repurchase a past loser, he may ignore the previous occurrence in his mental accounting. Then, it is also expectable that the framing for the repurchasing behavior of past winners or past losers is distinct. This behavior develops in a context of naïve reinforcement learning heuristic, where personally experienced outcomes are over-weighted compared to rational Bayesian learning. Investors repeat strategies in which they experienced success, even if that past success does not predict future success. The literature describes some findings in this line. Choi, Laibson, Madrian and Metrick (2009) find that investors who had particularly rewarding outcomes from saving in $401(\mathrm{k})$ increase their savings rate in $401(\mathrm{k})$ more than others with less rewarding experiences. Kaustia and Knüpfer (2008) find that Finnish investors are more likely to subscribe future IPOs if they experienced positive returns in their prior IPOs subscriptions. Malmendier and Nagel (2011) find that individual investors risk taking is strongly related with experienced returns: those who experienced high stock returns throughout their lives are more likely to take risk and hold more stocks. 
Additionally, the authors report that the more recent the experienced returns are, the stronger is the impact. A possible alternative explanation is that investors focus on their past winners because they have some advantage: experience, knowledge, expertise, etc. However, Strahilevitz, Odean and Barber (2011) find that the repurchase of previous winners does not yield superior adjusted returns in the subsequent 12 months, which casts some doubt on the argument of superior experience and knowledge associated with the repurchase of past winners.

\subsection{Repurchasing stocks that increased/decreased in price after being sold}

When considering the repurchase of a stock, investors also take into account the behavior of that stock subsequent to the sell. Investors engage in mental accounting simulations and think in terms of counterfactuals that can induce pleasure or regret. Counterfactual thinking is a mental construction of "what might have been" (Roese, 1996; 1997). Counterfactuals emerge mainly in response to a negative effect and generate feelings of pain and regret. It is an anticipated regret, since the investor did not experience it, but it feels like it is real when imagining the present situation, had he decided differently (Zeelenberg, 1999). Suppose the stock price increases after the sell. The investor engaging in counterfactual thinking concludes that he would be better off if he had kept the stock in his portfolio. To avoid this anticipated regret, he might not consider buying it again. On the contrary, suppose the stock price decreased after the sell. Now, the stock is a good choice in terms of counterfactual thinking, as long as the investor is in a better situation than he would have been if he had done nothing. Thus, repurchasing stocks that are losing value subsequent to the sell will emphasize the investor's ability and will make him proud of his investment decision. These mental simulations assume the existence of mental accounting and price anchoring, even after the sell. If the investor closes the mental account when he sells the stock, the anchor would be lost. The mental accounting and its prevalence over time even after the sell emphasizes the importance of past prices as anchors for current decisions. Moreover, the relevant prices are the prices of the previous transactions, meaning that the references are distinct for each investor. Weber and Welfens (2011), in an experimental setting, analyze the counterfactual thinking as a possible explanation for the preference to repurchase. If individuals have no responsibility in their past decisions, counterfactual thinking should be irrelevant. The experiment consists in comparing two groups: in one group the previous decision to purchase or sell was imposed, while the other group has the opportunity to decide. For the group where the decision was imposed, the preference for purchasing stocks at a price lower than the reference was considerably lower, which means that counterfactual thinking is truly the main explanation for this behavior.

Summarizing, when considering buying a stock, investors have an enormous amount of possibilities available. However, constrains of time and effort reduce the possibilities to a small number that they can effectively consider. Hence, investors tend to focus on a few stocks, and trade them many times, because they are more visible or familiar. However, investors do not buy these stocks discretionarily. Their personal experience with those stocks will affect their repurchasing preferences. The stock prices of their previous transactions are the most relevant input for the decision to repurchase, meaning that the references are individual and very particular to each investor. 


\section{Data}

Our primary data consist of a unique database of 5,128 individual investor accounts, with detailed information about their registered trades. The time period covered in this study is from $1^{\text {st }}$ August 2003 to $31^{\text {st }}$ July 2007, comprising about 1 million trades. The data are provided by a well-known Portuguese brokerage house and includes their discount brokerage clients. These investors make their own investing decisions without supervision or advice from the brokerage house. The largest majority of them trade online and the direct interaction with the brokerage house is almost inexistent. Our focus is on stock trades, thus we exclude all transactions of bonds, warrants, and options. The 5,128 investors covered in this study traded stocks at least once in the sample period. In total there are 343,360 stock trades (179,481 buys and 163,879 sells), involving 1,648 different stocks in 14 markets (countries) and 6 different currencies.

To study investors trading behavior, we construct individual stock portfolios, for each investor, based on the information about daily movements from their accounts. We follow the procedures of Odean (1998) and Grinblatt and Keloharju (2001b) to construct individual investor daily accounts. We net all trades, on the same day and security, for the same investor and ignore all sells for which it is not possible to identify the purchase date nor the corresponding price due to lack of information (i.e., we eliminate purchases occurring before the $1^{\text {st }}$ of August 2003 because we do not have information on their acquisition prices). We also adjust the data for every corporate action that occurs during the sample period (dividends, stock splits, mergers, etc). All the empirical analysis is conducted on a daily basis, using an end-of-day perspective, i.e. we use the intraday-trading information to determine the net daily movements. This means that multiple buys or sells of the same stock, in the same account, in the same day are aggregated. This procedure reduced the data from 343,360 trading entries to 117,976 . Throughout the entire sample period there are 1,167 corporate actions (840 of which relate to dividends) in the market and we adjust every account to these corporate actions.

In line with Odean (1998), Strahilevitz, Odean and Barber (2011), we construct the accounts starting from a zero initial balance at the beginning of the data period, and then we follow the chronological order for securities which acquisition dates and prices are known. The sells without a matching purchase with a known price are dropped (the elimination can be total or partial). Hence, we only consider investors that traded stocks at least once in the period. In the end, we are left with 4,428 investors with suitable trades and holding positions.

Table 1 describes the data after this process. We end-up with 111,616 suitable observations. On average, and ignoring the intra-day trading and sells with matching purchases, each investor has 25.21 net trades in the period. However, there are great differences among investors. The standard deviation of trading is 125.45 and the maximum number of trades for one investor is 3,516. We also find that stock accounts are under-diversified: on average, each investor holds a portfolio with 2.34 securities. This is not very different from what others find in the literature. For instance, Barber and Odean (2000) report that a typical individual investor holds a portfolio of only four stocks. The fact that each 
investor only trades a few stocks, besides the vast range of possibilities in the stock markets, may indicate that, due to their cognition constrains, investors tend to simplify the decision process and focus on a small number of stocks. Even though Portuguese investors can accede to other stock markets very easily, they concentrate their investments in few stocks from the Portuguese stock market. On average, each investor trades 4.73 stocks in the period (standard deviation of 12.14 and maximum of 287 stocks), meaning that investors trade many times the same stocks. Hence, one can affirm that past experience plays an important role, as investors keep trading what is familiar to them. In our sample, we have 61,123 purchases, on average 13.8 net purchases per investor (standard deviation of 66.78 and maximum number of net purchases for one investor of 1,936). Some of these purchases are of stock previously owned. Each time a purchase occurs, we classify it as repurchase if the investor owned and sold the stock in the prior year (quarter). We start looking for repurchases as of August 1, 2004 (November 1, 2003), using a moving window of the prior 365 (91) calendar days. We observe that 651 (742) investors engage in repurchasing behavior and 13,143 (13,848) repurchases are of stocks owned in the prior year (quarter). Those repurchases - the purchase of a stock previously owned and sold in the prior year (quarter) - represent $29 \%$ (24\%) of all purchases. We should notice, however, that the Portuguese stock market is small and the number of liquid stocks is limited. Hence, it is not surprising that rational investors frequently trade the same stocks. Nevertheless, a rational investor is not expected to use past experienced prices to decide which stocks to repurchase. We cannot even invoke that investors have similar expectations about future prices, since each investor's anchor is very particular.

\section{Who is repurchasing? What is being repurchased?}

Repurchasing is a large proportion of all stock purchases. We question whether the preference for repurchasing stocks is common to all investors or varies significantly across them and whether investor confine themselves to only certain types of stocks. Basically, in this section, we address two main questions: (1) which investors are more likely to repurchase stocks?; and (2) which stocks are more likely to be repurchased? We estimate probit regressions of the probability to repurchase a stock, rather than making a new purchase. Each time a purchase occurs, we classify it as repurchase if the investor owned and sold the stock in the prior year, starting looking one year after the beginning of the data period and using a moving window of the prior 365 calendar days. The independent variables comprise both stock and investor characteristics.

Table 2 reports the results of the probit estimation for the propensity to repurchase versus new purchase. The table reports marginal effects. The dependent variable of the model is a dummy representing the binary outcome: 1 for repurchase and 0 for new purchase. We consider 4,090 investors that purchase 1,508 different stocks, which generates 16,471 unique combinations of investor-stock for 46,504 observations. The $z$-stats are adjusted for clustering by stock in equations (1) to (3) and (8) and for clustering by investor in equations (4) to (7). Clustered standard errors correct for the possibility that the results are biased by a certain type of stocks or investors. In equation (9), we include investor 
dummies. Note that when we do so, investors that do not have both new purchases as well as repurchases in the period are automatically eliminated.

In the probit analysis our main variable of interest is the "Log of Daily Stock Volume, in Euros" (natural logarithm of the stock volume on the day of the purchase/repurchase, expressed in Euros). Barber and Odean (2008) argue that individuals buy stocks that catch their attention. The stock trading volume is a proxy for stock investor sentiment, visibility, and size. It can be viewed as an investor sentiment index (Baker and Stein, 2004; Baker and Wurgler, 2007). It can also be used as a proxy for market capitalization, which is positively related to analyst coverage (Bhushan, 1989), meaning that these stocks have greater visibility in the market. As trading volume is likely to increase when new information is disclosed and media coverage increases, daily stock volume is a good proxy for visibility and investor sentiment (Barber and Odean, 2008). We argue that when the investor previously owned a stock, his attention is directed to that stock and the likelihood of repurchasing it increases. When the daily stock volume increases, there are more investors buying (as well as selling) and we expect that those who previously owned the stock will buy it at a higher rate. The "Log of Daily Stock Volume, in Euros" is statistically, as well as economically, significant: doubling the daily stock volume (on the day that the repurchase occurs) increases the repurchasing behavior, at least, by $1.8 \%$ on average ${ }^{2}$. Overall, the results show that investors are more likely to repurchase stocks with larger daily volume.

In panel A of Table 2, we also test impact of other stock characteristics on the propensity for repurchasing. In particular, we include three dummy variables: "PSI-20 index dummy" that identifies stocks that belong to the PSI-20 index (a proxy for highly visible stocks); "PT dummy" that identifies Portuguese stocks ("home bias"); and "Euro dummy" that identifies stocks denominated in Euros ("Euro currency bias"). One should notice that the Portuguese stock market is very narrow and the trading volume is concentrated in a few companies of the PSI-20 index. The preference for these stocks is better captured by the variables of trading volume than by the PSI- 20 Index dummy. The results show some evidence, albeit weak, that belonging to the PSI-20 index has a positive impact on the probability of repurchasing a stock. Moreover, we find that the likelihood of repurchasing is lower for Portuguese stocks and higher for Euro currency stocks. This is consistent with the idea of Peng and Xiong (2006) that investors have scarce cognitive resources and attention constrains. Because attention tends to be more concentrated on those foreign stocks previously owned, investors are more likely to repurchase the same stocks than purchase new ones.

Panel B shows how stock prior performance influences the repurchasing behavior. For each stock, we determine the prior market-adjusted return for 12 historical intervals up to one year before each trade: current day of trading (day

\footnotetext{
2 We test alternatively the "Log of the Mean Stock Volume, in Euros" (natural logarithm of the mean of the stock volume for the entire data period, expressed in Euros) and find a positive and significant relation (coefficient of $0.6 \%$ ). We conclude that the stocks that are more visible over time (usually larger size stocks) are also more probable to be repurchased.
} 
0 ), the four prior days (days $-1,-2,-3$ and -4 ) and series of multiday (trading days -9 to $-5 ;-19$ to $-10 ;-39$ to $-20 ;-59$ to $-40 ;-119$ to $-60 ;-179$ to -120 and -239 to -180 , inclusive). We interact the prior stock market-adjusted returns with positive and negative dummies (the generated variables are reported in absolute values) in order to analyze whether positive or negative past returns influence the repurchasing decision. We consider the positive and negative past returns over 12 historical intervals and end up with 24 variables, similar to what Grinblatt and Keloharju (2001b) use to analyze the trading decision. Our estimation reports marginal effects, making the interpretation of the results more intuitive. We find evidence that positive or negative past market adjusted returns matter but in different intervals and directions. For instance, the likelihood of a stock repurchase is positively related to the lagged return (for the second and third prior days). However, from the fourth previous day up to the previous year, we find the opposite effect, which is statistically significant for almost every interval: the larger the positive market-adjusted return, the more likely is the investor to repurchase that stock, compared to simply buying a new stock that he had not owned in the previous year. When it comes to losses, the evidence indicates that in the prior two weeks (from the third to the 9th previous trading day), the more negative are the market-adjusted returns, the lower the propensity to repurchase the stocks previously owned. In the case of the third prior day, we observe that investors avoid to repurchase stocks with extreme positive (coefficient of 0.005 ) or negative performance (coefficient of 0.266 ), but the effect is much stronger on the negative side. This evidence suggests that previous performance is also an important factor in triggering the repurchase. We argue that, as investors owned the stock and maintain a mental account for it (in line with Arkes, Hirshleifer, Jiang and Lim, 2008), the prior positive or negative returns become more relevant for repurchases than for new purchases.

Panel $\mathrm{C}$ extends the previous regressions by including investor account characteristics, namely: activity (natural logarithm of the total number of investor trades, excluding day-trading, in the data period), diversification (diversification index defined below), performance (investor market-adjusted return), account value (natural logarithm of the mean of the stock account value, expressed in Euros), and experience (elapsed time since the account opening date, expressed in years at the beginning of the data period). The literature identifies these variables as proxies for investor sophistication (Feng and Seasholes, 2005; Nicolosi, Peng and Zhu, 2009; Grinblatt, Keloharju and Linnainmaa, 2012). Trading activity implies the assumption of trading costs, thus investors that are more active are the ones that lose the most, because their performance is diluted in trading costs (Odean, 1999; Barber and Odean, 2000). However, activity is also a source of experience and learning and trading costs tend to diminish with experience (Grinblatt, Keloharju and Linnainmaa, 2012). We find a positive and statistically significant coefficient for the variable "log of total trading" meaning that more active investors are more likely to repurchase a stock than less active investors. As trading activity doubles, the probability of repurchasing (versus new purchases) increases at least by $6.6 \%$, on average.

The number of stocks in account may not be an appropriate measure of diversification when the wealth of the portfolio is not evenly distributed. To better capture the level of portfolio diversification, we create a diversification index that takes into account the proportion invested in each stock. The Herfindahl-Hirschman Index (HHI) measures the degree 
of investor portfolio concentration, thus we use 1 - $\mathrm{HHI}$ to denote diversification ${ }^{3}$. We compute the proportion invested in each stock using the acquisition prices, net of trading costs, for each stock held at the end of each day of trading. The diversification index equals zero for absolutely non-diversified portfolios and 1 [100\%] for the ultimate diversified portfolio. The mean of the diversification index for the entire period is 0.26 , which is very low, according to Woerheide and Persson (1993) for whom index values of less than 0.85 represent not adequately diversified portfolios.

We find that the index of portfolio diversification has a negative impact on the probability of repurchasing a stock: a unit increase in the investor "Mean of Diversification Index" reduces the probability of repurchasing a stock previously owned by at least $30 \%$, on average.

To analyze the impact of investor performance on repurchasing behavior, we include in the probit model the "Mean of investor daily market-adjusted returns" (mean of the investor daily market-adjusted return, on the days when the investor has holdings in account) interacted with positive and negative dummies. This variable captures the investor real ability and skill, but not the perceived or realized performance in the moment of the decision. We find that the higher is the positive performance the more the investor avoids repurchases.

The independent variable "log of the mean of the stock account value" (natural logarithm of the mean of the stock account value, on the days when the investor has holdings in account, expressed in Euros) measures account value and it is a proxy for investor wealth. We find some evidence that the larger is the account value, the less likely is the investor to engage in repurchasing behavior. For instance, each time the stock account value doubles, the propensity to repurchase decreases at least by $3 \%$ on average. The results are in line with Grinblatt, Keloharju and Linnainmaa (2012) who find that wealthier investors are more likely to improve trading behavior. Another source of trading experience derives from the account age (Nicolosi, Peng and Zhu, 2009). "Account age" is the elapsed time (in years) since the account opening at the beginning of the data period. The mean of the account age is 3.9 years. We find some evidence, albeit weak, that account age reduces investor propensity to repurchase (coefficient of -0.016 from equation 7). Summarizing, our results suggest more sophisticated investors are less likely to repurchase a stock, since they will be less attached to the stocks previously hold and more willing to consider other investment opportunities.

In Panel D, we test whether certain investors' demographic characteristics affect their repurchasing behavior. To do so, we add to the previous regressions the following independent variables: gender, age (natural logarithm of the investor age in years at the beginning of the data period), marital status (1 if married, zero otherwise), and occupation.

3 Thus, the Diversification Index is: $D I=1-H H I=1-\sum_{i=1}^{n}\left(w_{i}\right)^{2}$, where DI represents the Diversification Index; HHI the HerfindahlHirschman Index for portfolio concentration; $w_{i}$ the proportion of portfolio value invested in security $i$, in decimal form; and $n$ the number of securities in the portfolio. 
Investor gender can be associated with more aggressive trading behavior, as men tend to trade more, are more overconfident and greater risk-takers than women (Barber and Odean, 2001). Investor age is also a source of experience and learning. Older investors are more risk averse while younger investor are more naïve (Dhar and Zhu, 2006). Older and experienced investors are more likely to make better investment decisions that reflect their accumulated knowledge of the market. However, as mentioned by Korniotis and Kumar (2011), the investment skills also deteriorate due to the adverse effects of cognitive aging. Thus, we end up with two competing hypotheses and it is not clear which one dominates. Finally, occupation and marital status may be associated to overconfidence and trading activity (Grinblatt and Keloharju, 2009). Due to missing data for some of the demographic variables, the number of observations used in the regressions is considerably lower. Generally, we do not find significant evidence that demographic characteristics influence the decision to purchase a stock previously owned, as the coefficients are not statistically different from zero. There are some exceptions though: in regression (8) we find that investors that are consultants are more likely to repurchase, whereas mangers or entrepreneurs are less likely to do so. There results, however, are not robust after we control for investor fixed effects, as shown in regression (9).

In conclusion, we find evidence less sophisticated investors (those who, besides their intensive trading, have underdiversified portfolios) are more likely to repurchase stocks. These characteristics are common among investors who trade as gamblers and usually underperform the average individual investor, as shown by Kumar (2009). Using different proxies for investor sophistication, such as better prior performance, wealth, and experience, lead to the same conclusion of a negative relation between investor sophistication and repurchasing behavior.

\section{Repurchasing behavior and price anchors}

From this section on, we narrow down our analysis to the investors ${ }^{4}$ that have repurchases in the data period and examine whether investors have preferences in the repurchasing behavior, by comparing their actual repurchasing behavior with the opportunities to do so. In this section, we use univariate analysis (following Strahilevitz, Odean and Barber (2011)) to determine the impact of prior selling prices and stock price evolution after the sell in the repurchasing decision. In the next section, we use a multivariate analysis to examine the impact of the price anchors and the investor and stock specific characteristics in the preferences on the repurchasing behavior.

According to rational economic theory, investors shall make buying and selling decisions based on the economic agents' expectations about future stock prices. Theoretically, buying and selling are two sides of the same coin.

\footnotetext{
${ }^{4} 651$ (742) investors when defining repurchase as the purchase of stocks that were owned and sold in the prior year (quarter). The smaller number of investors for the year window occurs because we start looking for repurchases one year after the beginning of the data period, while for the one quarter window, we start looking one quarter after (using thereafter a year/quarter moving window).
} 
However, for investors, and particularly for individual investors who do not short-sell that much, these decisions are fundamentally different. Individual investors accumulate knowledge and learn based on their experiences. Historical prices and, particularly, their reference historical prices, play an important role in their future decisions. Investor expectations can be very idiosyncratic, linked to what happened previously in their account and somehow disconnected from the relevant market information.

\subsection{Preferences for repurchasing prior winners}

We expect that, when considering the repurchase of one stock, investors prefer repurchasing their past winners rather than their past losers. Once they have a positive experience with that stock, they expect to repeat that experience. On the contrary, we expect investors to avoid past losers, as an attempt to avoid sources of pain and regret. To test whether investors prefer the repurchase of stocks previously sold for a gain or for a loss, it is not sufficient to compare the number of repurchases of stocks previously sold for a gain (prior winners) or a loss (prior losers) (Odean, 1998). The repurchases of prior winners/ losers by an investor have to be scaled by the opportunities to do so, that is the total number of prior gains/ losses, realized by that investor. We follow the measurement method of Strahilevitz, Odean and Barber (2011) and compute the ratios Proportion of Prior Winners Repurchased (PPWR) and Proportion of Prior Losers Repurchased (PPLR). The first divides the number of repurchases of stocks previously sold for a gain by the total number of stocks sold for a gain that could have been repurchased on the same day; the second divides the number of repurchases of stocks previously sold for a loss by the total number of stocks sold for a loss that could have been repurchased on that day. To classify prior losses/gains we compare the selling price with the reference price. In our study, the reference price is the volume weighted average acquisition price of the stock previously bought. If only one buying trade occurred, the average security price is the sole buying price registered in that account for that specific security.

Table 3 shows the investor preferences regarding the repurchase of stocks previously sold for a gain and for a loss, by testing the difference between the Proportion of Prior Winners Repurchased (PPWR) and the Proportion of Prior Losers Repurchased (PPLR). Table 3 Panel A compares the proportions aggregated over time and across all investors in the data set, while Panel B compares the mean of the proportions per investor ${ }^{5}$. The upper part of the panels shows the behavior observed as well as the opportunities to do so. Then, the bottom of the panels shows the proportions, their difference, and the t-statistics. Table 3 Panel A shows that, the difference in the proportions is statistically significant at the one percent significance level (t-statistic are -24.2 and -22.6 for one year and one quarter,

\footnotetext{
5 The results in Table 2 Panel A are drawn under the assumption that investors and days of trading are independent. Violating this assumption may artificially inflate the t-statistics. However, since the t-statistics in our tests are considerable high, that should not compromise the robustness of the results. Nevertheless, to overcome the concern about investor independency, in Panel B we use an alternative test, by computing the preference ratios by investor and testing the difference in means.
} 
respectively). On average, the proportion of repurchased prior winners is around 1.53 (1.46) times higher than the proportion of repurchased prior losers for stock owned during the year (quarter) prior to the repurchase, respectively. Therefore, we conclude that, in general, investors prefer to repurchase stocks previously sold for a gain. Table 2 Panel $B$ shows the results by investor. The difference of the mean of the proportions as well as its significance increase with this version of the test because we are weighting all investors equally, thus infrequent traders will tend to be overstated. This analysis ignores that accounts with more transactions provide estimations that are more accurate. It also assumes that the PPLR and PPWR are homoscedastic when they are clearly heteroscedastic. However, as we do not know the degree of independence of each account, the test serves its purpose. These findings suggest that investors may exhibit differences in their preferences related to their intensity of trading ${ }^{6}$.

\subsection{Preference for repurchasing stocks that dropped in price after being sold}

Although in efficient markets, investors should be indifferent to purchase stocks, which price went up or down after the last sell, in this section we test whether post-sell stock prices are anchors that affect investor repurchasing behavior. Using the same windows, we determine whether the stock was repurchased at a higher, lower or the same price, with respect to the last sell, based on the difference between selling price and repurchasing price. Then, we calculate the opportunities to repurchase stocks up since being sold and the opportunities to repurchase stocks down since being sold, by examining every stock that an investor could repurchase on that day. We check whether it could be repurchased at higher or lower price by comparing the selling price of the last sell in the year (quarter) window to the closing price of the repurchasing day. Finally, we aggregate the figures for each account over time and compute the Proportion of Stocks Up Since being Sold that were Repurchased (PSUSSR) and the Proportion of Stocks Down Since being Sold that were Repurchased (PSDSSR) similarly to the calculations of PPWR and PPLR.

Table 4 shows the ratios PSUSSR and PSDSSR and tests the differences for the one year/quarter windows. The results are quite strong in both cases: the differences in the proportions are significant (t-stats of 27 and 29). Therefore, we can conclude that investors prefer to repurchase stocks that have lost value, rather than gain, subsequent to a prior sell. This behavior can be explain in terms of mental accounting: when the stock price goes up after the sell, investors realize that they would be better off if they had held their position in that stock instead of selling it. Therefore, they

\footnotetext{
${ }^{6}$ Moreover, the magnitude of gains/losses may also have a different impact on the repurchasing preferences, if, for instance, investors are repurchasing their small prior winners and their larger prior losers. Thus, we also test the preferences for repurchasing stocks previously sold for a gain/loss, in value (Euros), using the value of prior winners/Losers repurchased compared to the opportunities to do so and get results in the same line as those reported in Table 2. The magnitudes of gains/losses have no substantial impact: for a year (quarter) window, repurchased winners have had an average gain of $786 €(788 €)$ and repurchased losers an average loss of $679 €(805 €)$. With respect to the potential repurchases, these figures decrease substantially for both: winners that could have been repurchased (but that were not) have had an average gain of $361 €(361 €)$ and losers and average loss of $426 €(386 €)$.
} 
will prefer to not buy the stock back later. On the contrary, when the price goes down after the sell, investors realize that they made a good decision and if they decide to buy the stock again, they will be better off than if they had kept the stock in account. Thus, the repurchase of stocks at a price lower than that for which they have sold it emphasizes positive counterfactuals.

In Table 5 we compute the proportion of stocks up since being sold that were repurchased (PSUSSR) and the proportion of stocks down since being sold that were repurchased (PSDSSR) for prior winners repurchased and for prior losers, separately for prior winners and for prior losers. The preference of repurchasing stocks that have lost value after the sell exists when the stock is either a prior winner or loser. However, the magnitude of the differences is much larger for prior winners (differences of 0.0420 and 0.0720 for one-year and one-quarter windows, respectively) than prior losers (with differences of only 0.0042 and 0.0190 for the one-year and one-quarter windows, respectively). Also, the statistical significant is much stronger for prior winners (with corresponding t-statistics of 30.76 and 30.16 ) than prior losers (with t-statistics of 2.77 and 6.18). This means that investors tracking on prices want both: prior winners that increased in price after being sold. If the first does not happen their interest decreases considerably. These findings are based on the assumption that investors keep the mental accounts opened, even when the stock is sold, and continue monitoring the prices evolution after the sell. We find that the differences we test are larger across the board when we consider the one-quarter window. This seems to indicate that past experiences may fade over time and the most recent ones are expected to have a stronger impact on the current investor repurchasing behavior.

\subsection{Repurchasing preferences of frequent traders and diversified investors}

The preferences for past winners and stocks that dropped in price after being sold uncovered above may differ among different groups of investors. A number of studies show that the levels of trading and diversification can affect investor behavior. For instance, Graham, Harvey and Huang (2009) find that investors who feel more competent trade more often. However, this sentiment of skill or knowledge is driven by overconfidence and results in poor performance (Barber and Odean, 2000). Other studies also find that investors learn by trading (Seru, Shumway and Stoffman, 2010) becoming more sophisticated and avoiding more behavioral biases. As Goetzmann and Kumar (2008), we observe that, in general, investors in our sample are under-diversified and trade many times the same stock. However, we also find considerable cross-section variation among investors in terms of diversification and trading activity that worth more detailed analysis.

In particular, we raise the question of whether the most active or diversified investors have less control over their accounts or are less prone to behavioral biases. In this section, we test whether the preferences for repurchasing past winners or stocks that dropped in price after being sold differ between groups of investors according to their trading activity and diversification. As measure of investor activity, we use the number of trades of an investor throughout the entire sample period. As a measure of investor diversification, we use the average number of stocks the investor has 
in his account. We used as cutoffs the percentiles 50, 75 to distinguish lower from upper groups. The percentiles are calculated after netting all trades for the same investor in the same day. In this analysis, we only consider investors who make repurchases of stocks that they have previously owned and sold in the past year. Panel A of Table 6 shows that the preference for repurchasing past winners is more frequent among investors with lower trading activity and less diversified. The differences are statistically significant at the $1 \%$, independent on which cutoff $\left(50^{\text {th }}\right.$ or $75^{\text {th }}$ percentile) we use. Similarly, in Panel A, we also find that the preference to repurchase stocks that dropped in price after being sold is more frequent among investors who trade more and are more diversified. In Table 6 Panel B, we estimate the difference in proportions per investor and then test the difference in means ${ }^{7}$, using the same cut-off percentiles. The methodology now ponders the observations aggregated per investor instead of per action of repurchasing. The stronger concentration of the preference for repurchasing past winners on bottom groups (less active and under-diversified investors) keeps up. The magnitude of the difference in means between groups increases (comparing to the difference between groups for the difference of proportions) although the significance remains about the same. When measuring the differences in the preference of repurchasing stocks that decreased in price after being sold, the difference between groups is reduced (not anymore statistically significant for the majority of the cut-offs). Overall, we conclude that investor activity and diversification influence the trading behavior and that active and more diversified investors pay less attention to past prices in their trading decisions. We believe that there are two main reasons to explain this behavior. Firstly, as investors become more active, the keeping their mental accounting becomes more difficult due to cognitive and memory limitations. Secondly, active investors accumulate more experience and, therefore, they learn that their past prices may not be so important as anchors for future trading decisions.

\section{Investor-specific and stock-specific determinants of the repurchasing behavior}

In this section, we continue our analysis focused only on the investors that have repurchases in the data period. We perform a multivariate analysis to identify investor or stock characteristics that affect the likelihood of repurchasing a stock that was previously owned by the investor. To do so, we estimate a probit model where the dependent variable is one if the investor repurchases a stock and zero if he has the opportunity to repurchase the stock but does not do it. Thus, for each day we identify not only the stock repurchases made by an investor, but also all the potential repurchases that an investor could make, even if he does not do so.

\footnotetext{
${ }^{7}$ We also test the Wilcoxon rank-sum and the difference in medians with similar results.
} 
In Table 7 we present the estimation of the probit model. For each variable, the table reports the marginal effect on the likelihood of repurchasing a stock given the pool of potential repurchases. We cluster standard errors by stock to mitigate potential biases originated by an abnormal concentration of repurchases of the same stock by several investors on the same day. Additionally, we include investor dummies to control for other non-identified investorspecific factors.

In Panel A of Table 7 we show how the repurchasing decision is affected by investor anchors. In equations (1) and (2) we analyze the repurchase of stocks previously sold for a gain versus loss, using a winner/loser dummy variable and the repurchase of stocks for a higher or lower price than the prior selling price, using a up/down dummy. The results are consistent with the ones shown in the univariate analysis: investors prefer to repurchase past winners and stocks which price has dropped after the prior sell, as the coefficients of dummies "winner/loser" ("up/down") are positive (negative) and statistically significant. Not only the existence of a gain/ loss in a prior sell can affect the investor repurchasing behavior, but more importantly the magnitude of that gain/ loss may affect the intensity of the repurchasing behavior (e.g., Kahneman and Tversky, 1979; 1982). From regressions (3) to (13), we replace the dummy variables by the actual percentage gain/ loss of the prior sell and the percentage change (up/ down) in stock price after the prior sell. We use these percentages are in absolute terms and multiply them by a dummy variable, "Positive" ("Negative"), that equals one if case the actual percentage is positive (negative), and zero otherwise. The results indicate that the magnitude of gains/losses also matters. We find evidence that the more positive are the percent gains of the prior sell, the higher is the probability that the stock is repurchased, as the coefficients of "Gain/loss (\%) * Positive" are all positive and statistically significant. As for the percent loss, we find some evidence that stocks with larger losses when sold are less likely to be repurchased later. However, these results are not robust after controlling for stock characteristics - although the coefficients of "Gain/loss * Negative" are negative, they are not statistically significant in regressions (4) to (8). Thus, we can infer from these results that investors are more sensitive to the magnitude of prior gains to make new repurchases than the magnitude of prior losses to avoid them. In untabulated estimations, we replaced the percent gain/loss by the logarithm of the absolute value of the gain/loss. The results remain statistically strong and the coefficients are 0.003 for gains and -0.001 for losses, reinforcing the conclusion that the wish of past winners is stronger (about the triple) than the avoidance for past winners. These findings also suggest that investors pay even more attention to absolute than relative values, as proposed by (Kahneman and Tversky, 1979). With respect to the stock price movement after the sell, as expected, there is a higher (lower) propensity to repurchase stocks that dropped (increased) in price after the sell, respectively. However, the impact is much stronger (the coefficients are much higher) for the first. These results suggest that narrow framing provided by mental accounting and loss aversion, according to the prospect theory, play a critical role in determining attitudes towards risk. The variable "log of trading days after the sell" controls for the time gap between the prior sell and the repurchase 
date. As the time gap increases, the probability of repurchasing that same stock decreases ${ }^{8}$. For instance, if the time gap (in days) between the sell and the repurchase doubles, the probability of repurchasing that stock decreases by $2 \%$. We also analyze whether some historical time gaps have stronger impact than others by testing 12 different time intervals, up to one year, between the sell and the repurchase. The results (untabulated) show a statistical strong positive correlation up to the third day. After one week, the coefficients become negative and increase as the time gap increases. This means that, after the sell, the probability of a repurchase up to the third day is very high and as the time gap increases the probability of repurchasing decreases, compared to the opportunities to do so. This evidence suggests that the stocks recently sold are the most likely to be repurchased, which means that the mental account for the stock sold may be kept open for a while but soon it loses importance.

Regressions in Panel B include stock characteristics, by adding to the previous regressions several proxies for stock visibility. In line with Barber and Odean (2008), we expect that individuals will more likely buy stocks that catch their attention. We use the "Log of Daily Stock Volume, in Euros" as a proxy for visibility and changes in investor sentiment and find a positive impact on the propensity to repurchase a stock against to pool of all possible repurchases - the coefficients are about 0.005 and strongly statistically significant in all specifications ${ }^{9}$. Overall, we find clear evidence of an investor preference for repurchasing larger and more visible stocks.

In addition, we also find that individuals are more likely to repurchase stocks that are denominated in Euros, from Portuguese companies, and the ones that belong to the Portuguese main market index - PSI-20. We are aware that these variables suffer from multicollinearity, so, we first include each one separately in the regressions, and then all of them together, and conclude that being a Portuguese company is the prevailing effect. There are two competitive motivations for the preference to repurchase domestic companies. One explanation is familiarity, a behavioral based reason. Investors prefer stocks that are closer and familiar to them. Other possible explanation is that investors have easier access to more accurate value-relevant information. We argue that familiarity is a strong reason. Even if familiarity does not mean to be particularly better informed, it means easier and less costly access to the information, without language and cultural barriers.

Panel $\mathrm{C}$ shows to what extent stock past returns affect the repurchasing decision, by including in the regressions positive and negative stock market-adjusted returns in 12 historical intervals. We would expect that the signs of the coefficients are negative for stock market-adjusted returns interacted with the dummy variable "Positive" and positive

\footnotetext{
8 The mean repurchase occurs 52 calendar days after the sell (standard deviation of 0.6639192 ), while the mean potential repurchase is 129 calendar days after the sell (standard deviation of 0.2118862).

${ }^{9}$ Alternatively, we also estimate the same regressions using the "Log of the Mean Stock Volume, in Euros" (natural logarithm of the mean of the stock volume for the entire data period, expressed in Euros.) as a proxy for firm size and global visibility. The results (untabulated) are very similar, but slightly smaller in magnitude - the coefficients are on average 0.003 , statistically significant at $1 \%$.
} 
for stock market-adjusted returns interacted with the dummy "Negative". However, we not observe this pattern. From the first up to the third lagged trading day, before the actual or potential repurchase, positive past market-adjusted returns are negatively related to the propensity of repurchasing. From the fourth up to the 119th lagged trading day, positive market-adjusted past returns have no significant impact on the decision the repurchase a stock, whereas, beyond the 120th lagged trading day, positive market-adjusted returns are significantly and positively correlated with the repurchasing decision. On the contrary, the results show a strong preference for the repurchase of stocks with recent negative performance. Up to the 59th lagged trading day, the more negative is the stock performance, the higher is the propensity to repurchase, as the coefficients of the interaction between stock market-adjusted returns and the dummy "Negative" are positive and statistically significant. This preference is very strong for stocks with negative performance in the prior week (e.g. a negative performance of an additional $1 \%$ in the second lagged day increases the propensity to repurchase by $36 \%$ on average) and decreases for longer lagged periods, becoming negligible after 59 trading days. Overall, in line with the literature (Grinblatt and Keloharju, 2001b; Kaniel, Saar and Titman, 2008), the more recent and higher is the negative adjusted stock return, the more likely is the investor to repurchase that stock. Since negative returns beyond 59 lagged trading days appear to have little impact on the repurchasing decision, we seem to find evidence of contrarian behavior up to trading days and momentum beyond 120 trading days. We can relate this short-term contrarian behavior with the preference for repurchasing in a downward trend after the sell that we find in equations (1) and (2). Although, a stock with negative lagged performance did not necessarily observe a downward movement after the sell, as the latter depends on the investor timing, we can expect that many times these two situations overlap. From our results, we conclude that both effects coexist: investors prefer to repurchase stocks with recent negative past performance and, particularly, those that performed poorly after the sell.

In panel $D$, we add account characteristics to the regressions, namely, trading activity, diversification, performance and, value of the stock holdings, and total account value. We measure investor trading activity by the logarithm of investor total number of trades over the entire sample period and find that the more active investors tend to repurchase less. For instance, doubling the number of trades reduces the repurchasing behavior, at least, by $15 \%$ on average. In our sample investors trade, on average, 25 times in the period, but there are great differences among them (standard deviation of 125 and the most active investor with 3,515 trades in the period). Thus we argue that the most active investors have cognitive and memory constrains that prevent them from monitoring past experienced prices so intensely. Additionally, these investors are more experienced and expectedly more sophisticated, therefore they should disregard past experienced prices in their buying decision. In the regressions, we also include the Daily Diversification Index (investor diversification on the day of the repurchase). We find that the investors who have more underdiversified accounts at the moment of the decision repurchase significantly less (coefficient of -0.02). We argue that if at a given time, an investor is particularly concentrated in few stocks, he may prefer to continue concentrated (avoiding repurchasing) for that reasons that generated that choice for concentration. Particularly, investors that are concentrated in one stock avoid the repurchase of others at that moment. On the contrary, when we, alternatively, 
use the Mean of the Diversification Index (untabulated, due the high level of correlation with Daily Diversification Index), we find that investors with more underdiversified accounts tend to repurchase more.

With respect to investor performance, we find that the larger the magnitude of the market-adjusted returns (positive or negative), the more likely it is that the investor will repurchase ${ }^{10}$. Thus, we conclude that investors with more extreme positive and negative average past market-adjusted returns are the ones more likely to repurchase. Using the total period market-adjusted returns, we are relating the repurchasing decision to a return that is not completely produced when the decision is made. Therefore, this variable proxies for real investor ability and skills but not necessarily for perceived performance.

Finally, in the last two regressions we include variables that measure account value (the total Euro amount invested in all securities in the investor's account) and the value of investor stock holdings (total amount in Euro invested in all stocks). We find that both coefficients are not statistically significant to explain the repurchase behavior. We also control for investor demographics (age, gender, status, occupation) and investor market adjusted returns before the repurchase (over the same lagged intervals used for stock) and conclude that these variables are not significant to explain preferences for repurchasing.

\section{Conclusions}

In the stock market, when it comes to deciding what to buy the possibilities are endless. Nevertheless, we observe, for a sample of 5,128 investors, that repurchases represent $29 \%$ of all purchases. Still, the literature has paid little attention to this subset of purchases. We present a comprehensive analysis of the determinants of the repurchasing of stocks currently or previously owned. We describe similarities and heterogeneity in investor repurchasing behavior, analyzing together numerous variables, and distinguishing their contributions.

Based on a unique database of 5,128 investors trading in the period from $1^{\text {st }}$ August 2003 to $31^{\text {st }}$ July 2007, we find evidence of the preference for repurchasing stocks that were "prior winners" (i.e. stocks that were previously sold for a gain) and also a preference for stocks which price has dropped after the prior sell. Our results are in line with Strahilevitz, Odean and Barber (2011), not only at the aggregated level, as these authors, but also at the individual level. These findings suggest that the decision to repurchase a stock is strongly behavioral and emotional-based,

${ }^{10}$ We also test lagged investor market-adjusted returns for the same 12 intervals used for stock market-adjusted returns interacted with positive and negative dummies and find that the likelihood of repurchasing is not affected by the investor past performance (untabulated). 
associated with mental accounting framing, counterfactual thinking, loss aversion and regret aversion (experienced or anticipated).

Furthermore, we test the importance of stock and investor characteristics to explain this behavior. We find that reference prices, prior stock returns, visibility, and investor performance and sophistication are determinants of the repurchasing behavior. The propensity to repurchase versus a new stock purchase is positively related with firm size, stock visibility, Euro currency stocks, prior positive stock performance, and unsophisticated investors.

When testing the likelihood of a repurchase from the entire set of all possible repurchases available to the investor, we conclude that past experienced prices are strong anchors for the decision to purchase current or previous holdings. Being a prior or current winner matters as well the price evolution after the sell. The magnitudes of these outcomes also affect the decision. We find evidence that the larger the prior gain or the decrease in price after the sell, the more likely the investor is to purchase the same stock again. Thus, the magnitude of the gain or loss matter for the repurchasing decision-. Additionally, we find that the purchase of prior winners is more likely for domestic visible stocks with negative market-adjusted returns, and particularly for less active, under-diversified and poor-performing investors. Finally, we find that demographic characteristics (such as age, gender, marital status and profession) are not relevant to explain investor repurchasing behavior. 


\section{List of references}

Ariely, D., G. Loewenstein and D. Prelec (2003). "Coherent Arbitrariness: Stable Demand Curves without Stable Preferences*." Quarterly Journal of Economics 118(1): 73-105.

Arkes, H. R., D. Hirshleifer, D. Jiang and S. Lim (2008). "Reference Point Adaptation: Tests in the Domain of Security Trading." Organizational Behavior and Human Decision Processes 105(1): 67-81.

Baker, M. and J. C. Stein (2004). "Market Liquidity as a Sentiment Indicator." Journal of Financial Markets 7(3): 271299.

Baker, M. and J. Wurgler (2007). "Investor Sentiment in the Stock Market." Journal of Economic Perspectives 21(2): 129-152.

Barber, B. and T. Odean (2000). "Trading Is Hazardous to Your Health: The Common Stock Investment Performance of Individual Investors." Journal of Finance 55(2): 773-806.

Barber, B. and T. Odean (2001). "Boys Will Be Boys: Gender, Overconfidence, and Common Stock Investment*." Quarterly Journal of Economics 116(1): 261-292.

Barber, B. and T. Odean (2008). "All That Giltters: The Effect of Attention and News on the Buying Behavior of Individual and Institutional Investors." Review of Financial Studies 21(2): 785-818.

Barber, B., T. Odean and N. Zhu (2009). "Systematic Noise." Journal of Financial Markets 12(4): 547-569.

Bhushan, R. (1989). "Firm Characteristics and Analyst Following." Journal of Accounting and Economics 11(2-3): 255274.

Calvet, L. E., J. Y. Campbell and P. Sodini (2007). "Down or Out: Assessing the Welfare Costs of Household Investment Mistakes." Journal of Political Economy 115 707-747.

Calvet, L. E., J. Y. Campbell and P. Sodini (2009a). "Fight or Flight? Portfolio Rebalancing by Individual Investors." Quarterly Journal of Economics 124(1): 301-348.

Calvet, L. E., J. Y. Campbell and P. Sodini (2009b). "Measuring the Financial Sophistication of Households." American Economic Review 99(2): 393-398.

Campbell, J. Y. (2006). "Household Finance." Journal of Finance 61(4): 1553-1604.

Choi, J. J., D. Laibson, B. C. Madrian and A. Metrick (2009). "Reinforcement Learning and Savings Behavior." Journal of Finance 64(6): 2515-2534.

De Bondt, W. F. M. (1998). "A Portrait of the Individual Investor." European Economic Review 42(3-5): 831-844.

Dhar, R. and N. Zhu (2006). "Up Close and Personal: An Individual Level Analysis of the Disposition Effect." Management Science 52(5): 726-740.

Feng, L. and M. S. Seasholes (2004). "Correlated Trading and Location." Journal of Finance 59(5): 2117-2144.

Feng, L. and M. S. Seasholes (2005). "Do Investor Sophistication and Trading Experience Eliminate Behavioral Biases in Financial Markets?" Review of Finance 9(3): 305-351.

Goetzmann, W. N. and A. Kumar (2008). "Equity Portfolio Diversification." Review of Finance 12(3): 433-463.

Graham, J. R., C. R. Harvey and H. Huang (2009). "Investor Competence, Trading Frequency, and Home Bias." Managment Science 55(7): 1094-1106.

Grinblatt, M. and M. Keloharju (2001a). "How Distance, Language, and Culture Influence Stockholdings and Trades." Journal of Finance 56(3): 1053-1073.

Grinblatt, M. and M. Keloharju (2001b). "What Makes Investors Trade?" Journal of Finance 56(2): 589-616.

Grinblatt, M. and M. Keloharju (2009). "Sensation Seeking, Overconfidence, and Trading Activity." Journal of Finance 64(2): 549-578.

Grinblatt, M., M. Keloharju and J. T. Linnainmaa (2012). "Iq, Trading Behavior, and Performance." Journal of Financial Economics 104(2): 339-362.

Huberman, G. (2001). "Familiarity Breeds Investment." Review of Financial Studies 14(3): 659-680. 
Ivkovich, Z., C. Sialm and S. Weisbenner (2008). "Portfolio Concentration and the Performance of Individual Investors." Journal of Financial and Quantitative Analysis 43(3): 613-655.

Ivkovich, Z. and S. Weisbenner (2005). "Local Does as Local Is: Information Content of the Geography of Individual Investors' Common Stock Investments." Journal of Finance 60(1): 267-306.

Kahneman, D. and A. Tversky (1979). "Prospect Theory: An Analysis of Decision under Risk." Econometrica 47(2): 263292.

Kahneman, D. and A. Tversky (1982). "The Psychology of Preferences." Scientific American 246(1): 160-173.

Kaniel, R., G. Saar and S. Titman (2008). "Individual Investor Trading and Stock Returns." Journal of Finance 63(1): 273-310.

Kaustia, M. and S. Knüpfer (2008). "Do Investors Overweight Personal Experience? Evidence from Ipo Subscriptions." Journal of Finance 63(6): 2679-2702.

Korniotis, G. M. and A. Kumar (2011). "Do Older Investors Make Better Investment Decisions?" Review of Economics and Statistics 93(1): 244-265.

Kumar, A. (2009). "Who Gambles in the Stock Market?" Journal of Finance 64(4): 1889-1933.

Linnainmaa, J. T. (2011). "Why Do (Some) Households Trade So Much?" Review of Financial Studies 24(5): 16301666.

Malmendier, U. and S. Nagel (2011). "Depression Babies: Do Macroeconomic Experiences Affect Risk Taking?*." Quarterly Journal of Economics 126(1): 373-416.

Massa, M. and A. Simonov (2005). "Behavioral Biases and Investment." Review of Finance 9(4): 483-507.

Nicolosi, G., L. Peng and N. Zhu (2009). "Do Individual Investors Learn from Their Trading Experience?" Journal of Financial Markets 12(2): 317-336.

Odean, T. (1998). "Are Investors Reluctant to Realize Their Losses?" Journal of Finance 53(5): 1775-1798.

Odean, T. (1999). "Do Investors Trade Too Much?" American Economic Review 89(5): 1279-1298.

Peng, L. and W. Xiong (2006). "Investor Attention, Overconfidence and Category Learning." Journal of Financial Economics 80(3): 563-602.

Roese, N. (1996). "Counterfactuals, Causal Attributions, and the Hingsight Bias: A Conceptual Integration." Journal of Experimental Social Psychology 32: 197-227.

Roese, N. (1997). "Counterfactual Thinking." Psychological Bulletim 121(1): 133-148.

Seru, A., T. Shumway and N. Stoffman (2010). "Learning by Trading." Review of Financial Studies 23(2): 705-739.

Statman, M. (2011). What Investors Really Want: Know What Drives Investor Behavior and Make Smarter Financial Decisions, MacGrawHill

Strahilevitz, M., T. Odean and B. Barber (2011). "Once Burned, Twice Shy: Naive Learning, Counterfactuals, and the Repurchase of Stocks Previously Sold." Journal of Marketing Research 48(SPL): S102-S120.

Thaler, R. (1985). "Mental Accounting and Consumer Choice." Marketing Science 4(3): 199-214.

Weber, M. and F. Welfens (2011). "The Follow-on Purchase and Repurchase Behavior of Individual Investors: An Experimental Investigation." Die Betriebswirtschaft 71: 139-154.

Woerheide, W. and D. Persson (1993). "An Index of Portfolio Diversification." Financial Services Review 2(2): 73-85.

Zeelenberg, M. (1999). "Anticipated Regret, Expected Feedback and Behavioral Decision Making." Journal of Behavioral Decision Making 12(2): 93-106. 
- Accounts' age: Elapsed time since account opening in years, at the beginning of the data period.

- Diversification: Average number of stocks in investor account, determined based on days that investor has holdings in account.

- Daily Diversification Index: Herfindahl-Hirschman Index that takes into account the amount invested in each stock and captures the degree of investor portfolio diversification, determined for each investor each day he has holdings in account, given by the following formula: $1-H H I=1-\sum_{i=1}^{n}\left(w_{i}\right)^{2}$, where $\mathrm{HHI}$ the Herfindahl-Hirschman Index for portfolio concentration; $w_{i}$ the proportion of portfolio value invested in security $i$, in decimal form; and $n$ the number of securities in the portfolio.

- Diversification Index: Mean of the Daily Diversification Index by Investor, determined each day the investor has holding in account.

- Euro dummy: Dummy variable that equals 1 if the stock is denominated in Euro currency.

- Gain/loss(\%): Percentage outcome (gain or loss) previously obtained with the stock, determined by comparing the average acquisition price with the selling price.

- Gender: Dummy variable that equals 1 if the investor is a men and 0 she is a women.

- Log of age: Natural logarithm of the investor age in years at the beginning of the data period.

- Log of Daily Stock Volume, in Euros: Natural logarithm of the daily stock volume, expressed in Euros. It is determined every stock trading day and is used as a proxy for stock visibility at that moment.

- Log of gain/loss: Natural logarithm of the absolute value of the outcome (gain or loss) by comparing the average acquisition price with the selling price, expressed in Euros.

- Log of the mean of the stock account value: Natural logarithm of the mean of the stock account value, expressed in Euros. Proxy of investor wealth.

- Log of the mean of the stock total value: Natural logarithm of the total (stocks and other securities) account value, expressed in Euros. Proxy of investor wealth.

- Log of the Mean Stock Volume, in Euros: Natural logarithm of the mean of the stock volume for the entire data period, expressed in Euros. Proxy of size and stock global visibility.

- Log of total trading: Natural logarithm of the total number of investor trades (excluding day-trading) in the data period.

- Log of trading days after the sell: Natural logarithm of the interval of trading days between the sell and the (real or potential) repurchase.

- Mean of Investor Daily Market-Adjusted Returns (MAR): mean of the investor daily market-adjusted return, on the days when the investor has holdings in account. We use PSI20 index as the proxy for the market returns.

- Occupation: Dummy variable that takes the value of 1 for the specified occupation category and zero otherwise.

PSI20 index dummy: Dummy variable that equals 1 if the stock belongs to the PSI20 index.

PT dummy: Dummy variable that equals 1 if the stock is Portuguese.

- Status: Dummy variable that equals 1 for the specified status category and zero otherwise.

- Stock MAR [day(s)]: Stock market-adjusted return in the given trading day, or interval of trading days, before de purchase decision. We consider 12 historical intervals: current day (day 0), the four prior days (days $-1,-2,-3$ and -4 ) and series of multiday (trading days -9 to $-5 ;-19$ to $-10 ;-39$ to $-20 ;-59$ to $-40 ;-119$ to $-60 ;-179$ to -120 and -239 to -180 , inclusive). We use PSI20 index as the proxy for the market returns.

- Up/down dummy: Dummy variable that equals 1 if the price has an upward movement between the prior sell and the (real or potential) repurchase and 0 otherwise.

- Up/Down(\%): Percentage variation of the stock price in the interval between the prior sell and the (real or potential) repurchase.

- Winner/loser dummy: Dummy variable that equals 1 if the stock is a prior winner and 0 otherwise. 
Table 1: Summary Statistics

This Table describes the data after the process of daily account construction. Trades are determined ignoring the intra-day trading and sells with matching purchase. Purchases are classified as repurchases if the investor owned and sold the stock in the prior year (quarter). We start looking for repurchases as of August 1, 2004 (November 1, 2003), using a moving window of the prior 365 (91) calendar days.

\begin{tabular}{lrrrrrr}
\hline & \# observations & \# investors & Mean & St. Deviation & Maximum & $€$ value \\
\hline Trades (buys and sells) & 111,616 & 4,428 & 25.21 & 125.45 & 3,516 & $1,487,800,379$ \\
Different Stocks traded & 1,604 & 4,428 & 4.73 & 12.14 & 287 & $1,487,800,379$ \\
Purchases & 61,123 & 4,428 & 13.80 & 66.37 & 1,936 & $826,728,812$ \\
Repurchases (1Y) & 13,143 & 651 & 20.19 & 43.26 & 481 & $9,907,340$ \\
Repurcahses (1Q) & 13,848 & 742 & 18.66 & 38.82 & 416 & $10,974,980$ \\
\hline
\end{tabular}


Table 2: Determinants of the propensity to repurchase (versus new repurchases)

This Table reports the results of probit regressions that estimate the propensity to repurchase versus new purchase. The values in the Table are marginal effects. The sample is for the period from 1-8-2003 to 31-07-2007. The dependent variable is a dummy representing the binary outcome: 1 for repurchase and 0 for new repurchase. We consider 4,090 investors that purchase 1,508 stocks, which generates 16,471 unique combinations of investor-stock for 46,504 observations (13,500 of them classified as repurchases). The variables generated by interaction with "Positive" and "Negative" dummies are reported in absolute values. Independent variables are described in Appendix I. Robust Z-stats are adjusted for clustering by stock in equations (1) to (3) and (8) and for clustering by investor in equations (4) to (7). Equation (8) considers investor dummies. $* * *$, and $* * *$ stand for statistical significance at $10 \%, 5 \%$, and $1 \%$, respectively.

(1)

(2)

(3)

(4)

(5)

(6)

(7)

(8)

\begin{tabular}{|c|c|c|c|c|c|c|c|c|}
\hline \multicolumn{9}{|l|}{ Panel A: Stock characteristics } \\
\hline Log of Daily Stock Volume, in Euros & $\begin{array}{c}0.023^{* * *} \\
(5.78)\end{array}$ & $\begin{array}{c}0.021^{* * *} \\
(4.49)\end{array}$ & $\begin{array}{c}0.021^{* * *} \\
(4.88)\end{array}$ & $\begin{array}{c}0.018^{* * *} \\
(14.36)\end{array}$ & $\begin{array}{c}0.018^{* * *} \\
(14.60)\end{array}$ & $\begin{array}{c}0.020^{* * *} \\
(16.03)\end{array}$ & $\begin{array}{c}0.020 * * * \\
(16.52)\end{array}$ & $\begin{array}{c}0.019^{* * *} \\
(9.60)\end{array}$ \\
\hline PSI20 index dummy & & $\begin{array}{l}0.040 \\
(1.04)\end{array}$ & $\begin{array}{l}0.045 \\
(1.31)\end{array}$ & $\begin{array}{c}0.049 * * \\
(2.29)\end{array}$ & $\begin{array}{c}0.044^{* *} \\
(2.11)\end{array}$ & $\begin{array}{c}0.044^{* *} \\
(2.38)\end{array}$ & $\begin{array}{c}0.067^{* * *} \\
(3.49)\end{array}$ & $\begin{array}{c}0.090^{* * *} \\
(4.03)\end{array}$ \\
\hline PT dummy & & $\begin{array}{c}-0.073 * * \\
(-2.13)\end{array}$ & $\begin{array}{c}-0.060^{*} \\
(-1.87)\end{array}$ & $\begin{array}{c}-0.052^{* *} \\
(-2.32)\end{array}$ & $\begin{array}{c}-0.048^{* *} \\
(-2.19)\end{array}$ & $\begin{array}{l}-0.040^{*} \\
(-1.88)\end{array}$ & $\begin{array}{l}-0.019 \\
(-0.71)\end{array}$ & $\begin{array}{c}-0.053^{* *} \\
(-2.30)\end{array}$ \\
\hline EUR dummy & & $\begin{array}{c}0.106^{* * *} \\
(6.01)\end{array}$ & $\begin{array}{c}0.097 * * * \\
(5.52) \\
\end{array}$ & $\begin{array}{c}0.076^{* *} \\
(2.37) \\
\end{array}$ & $\begin{array}{c}0.073^{* *} \\
(2.30) \\
\end{array}$ & $\begin{array}{c}0.069^{* *} \\
(2.29)\end{array}$ & $\begin{array}{c}0.105^{* *} \\
(2.34)\end{array}$ & $\begin{array}{c}0.109 * * * \\
(3.27)\end{array}$ \\
\hline \multicolumn{9}{|c|}{ Panel B: Stock Market adjusted return in the given interval before the purchase } \\
\hline Stock MAR day0*Positive & & & $\begin{array}{l}0.015 \\
(0.38)\end{array}$ & $\begin{array}{l}0.022 \\
(0.60)\end{array}$ & $\begin{array}{l}0.021 \\
(0.57)\end{array}$ & $\begin{array}{l}-0.004 \\
(-0.09)\end{array}$ & $\begin{array}{l}-0.009 \\
(-0.18)\end{array}$ & $\begin{array}{l}-0.004 \\
(-0.08)\end{array}$ \\
\hline Stock MAR day-1*Positive & & & $\begin{array}{l}-0.060 \\
(-0.30)\end{array}$ & $\begin{array}{l}0.067 \\
(0.73)\end{array}$ & $\begin{array}{l}0.052 \\
(0.57)\end{array}$ & $\begin{array}{l}-0.066 \\
(-0.65)\end{array}$ & $\begin{array}{l}-0.058 \\
(-0.46)\end{array}$ & $\begin{array}{l}-0.114 \\
(-0.91)\end{array}$ \\
\hline Stock MAR day-2*Positive & & & $\begin{array}{c}-0.004 * \\
(-1.76)\end{array}$ & $\begin{array}{c}-0.005^{* *} \\
(-1.99)\end{array}$ & $\begin{array}{l}-0.004 * \\
(-1.87)\end{array}$ & $\begin{array}{l}-0.044 \\
(-0.43)\end{array}$ & $\begin{array}{l}-0.134 \\
(-0.95)\end{array}$ & $\begin{array}{l}-0.110 \\
(-0.99)\end{array}$ \\
\hline Stock MAR day-3*Positive & & & $\begin{array}{c}-0.005^{* * *} \\
(-2.61)\end{array}$ & $\begin{array}{c}-0.006^{* * *} \\
(-2.82)\end{array}$ & $\begin{array}{c}-0.005^{* * *} \\
(-2.72)\end{array}$ & $\begin{array}{c}-0.007^{* *} \\
(-2.13)\end{array}$ & $\begin{array}{l}0.009 \\
(0.10)\end{array}$ & $\begin{array}{l}0.036 \\
(0.33)\end{array}$ \\
\hline Stock MAR day-4*Positive & & & $\begin{array}{c}0.393^{* * *} \\
(3.08)\end{array}$ & $\begin{array}{c}0.339 * * * \\
(3.28)\end{array}$ & $\begin{array}{c}0.328^{* * *} \\
(3.24)\end{array}$ & $\begin{array}{c}0.227^{* *} \\
(2.43)\end{array}$ & $\begin{array}{l}0.151 \\
(1.49)\end{array}$ & $\begin{array}{l}0.151 \\
(1.26)\end{array}$ \\
\hline Stock MAR days $[-9,-5]^{*}$ Positive & & & $\begin{array}{l}-0.004 \\
(-1.32)\end{array}$ & $\begin{array}{l}-0.001 \\
(-0.54)\end{array}$ & $\begin{array}{l}-0.000 \\
(-0.09)\end{array}$ & $\begin{array}{l}-0.001 \\
(-0.22)\end{array}$ & $\begin{array}{l}0.000 \\
(0.15)\end{array}$ & $\begin{array}{l}0.002 \\
(0.66)\end{array}$ \\
\hline Stock MAR days[-19,-10]*Positive & & & $\begin{array}{c}0.246 * * * \\
(6.25)\end{array}$ & $\begin{array}{c}0.210^{* * *} \\
(6.16)\end{array}$ & $\begin{array}{c}0.209 * * * \\
(6.14)\end{array}$ & $\begin{array}{c}0.172^{* * *} \\
(5.17)\end{array}$ & $\begin{array}{c}0.150 * * * \\
(4.35)\end{array}$ & $\begin{array}{c}0.173^{* * *} \\
(3.99)\end{array}$ \\
\hline Stock MAR days[-39,-20]*Positive & & & $\begin{array}{l}0.000 \\
(0.09)\end{array}$ & $\begin{array}{l}0.000 \\
(0.08)\end{array}$ & $\begin{array}{l}0.000 \\
(0.13)\end{array}$ & $\begin{array}{l}0.000 \\
(0.07)\end{array}$ & $\begin{array}{c}0.088^{* * *} \\
(4.21)\end{array}$ & $\begin{array}{c}0.109 * * * \\
(3.58)\end{array}$ \\
\hline Stock MAR days[-59,-40]*Positive & & & $\begin{array}{c}0.150 * * * \\
(5.14)\end{array}$ & $\begin{array}{c}0.131^{* * *} \\
(5.61)\end{array}$ & $\begin{array}{c}0.128^{* * *} \\
(5.54)\end{array}$ & $\begin{array}{c}0.107^{* * *} \\
(4.81)\end{array}$ & $\begin{array}{c}0.114^{* * *} \\
(4.21)\end{array}$ & $\begin{array}{c}0.132^{* * *} \\
(4.30)\end{array}$ \\
\hline Stock MAR days $[-119,-60] *$ Positive & & & $\begin{array}{c}0.099 * * * \\
(3.88)\end{array}$ & $\begin{array}{c}0.086^{* * *} \\
(4.30)\end{array}$ & $\begin{array}{c}0.084^{* * *} \\
(4.28)\end{array}$ & $\begin{array}{c}0.073^{* * *} \\
(3.77)\end{array}$ & $\begin{array}{c}0.084^{* * *} \\
(4.02)\end{array}$ & $\begin{array}{c}0.096^{* * *} \\
(3.96)\end{array}$ \\
\hline Stock MAR days[-179,-120]*Positive & & & $\begin{array}{c}0.068^{* * *} \\
(3.67)\end{array}$ & $\begin{array}{c}0.061^{* * *} \\
(3.59)\end{array}$ & $\begin{array}{c}0.060^{* * *} \\
(3.59)\end{array}$ & $\begin{array}{c}0.052^{* * *} \\
(3.37)\end{array}$ & $\begin{array}{c}0.066^{* * *} \\
(3.10)\end{array}$ & $\begin{array}{c}0.076^{* * *} \\
(3.06)\end{array}$ \\
\hline Stock MAR days[-239,-180]*Positive & & & $\begin{array}{c}0.096 * * * \\
(5.39)\end{array}$ & $\begin{array}{c}0.096 * * * \\
(6.25)\end{array}$ & $\begin{array}{c}0.095^{* * *} \\
(6.22)\end{array}$ & $\begin{array}{c}0.089 * * * \\
(5.86)\end{array}$ & $\begin{array}{c}0.098^{* * *} \\
(5.27)\end{array}$ & $\begin{array}{c}0.098^{* * *} \\
(4.07)\end{array}$ \\
\hline Stock MAR day $0 *$ Negative & & & $\begin{array}{l}0.064 \\
(0.45)\end{array}$ & $\begin{array}{l}-0.013 \\
(-0.15)\end{array}$ & $\begin{array}{l}-0.019 \\
(-0.21)\end{array}$ & $\begin{array}{l}-0.096 \\
(-1.09)\end{array}$ & $\begin{array}{c}-0.208^{*} \\
(-1.77)\end{array}$ & $\begin{array}{l}-0.158 \\
(-0.88)\end{array}$ \\
\hline Stock MAR day- $1 *$ Negative & & & $\begin{array}{l}-0.052 \\
(-0.44)\end{array}$ & $\begin{array}{l}-0.098 \\
(-0.89)\end{array}$ & $\begin{array}{l}-0.107 \\
(-0.98)\end{array}$ & $\begin{array}{c}-0.236 * * \\
(-2.31)\end{array}$ & $\begin{array}{c}-0.227^{*} \\
(-1.72)\end{array}$ & $\begin{array}{l}-0.251 \\
(-1.45)\end{array}$ \\
\hline Stock MAR day-2*Negative & & & $\begin{array}{l}-0.080 \\
(-0.73)\end{array}$ & $\begin{array}{l}-0.077 \\
(-0.77)\end{array}$ & $\begin{array}{l}-0.083 \\
(-0.83)\end{array}$ & $\begin{array}{l}-0.099 \\
(-1.16)\end{array}$ & $\begin{array}{l}-0.152 \\
(-1.39)\end{array}$ & $\begin{array}{l}-0.151 \\
(-1.01)\end{array}$ \\
\hline Stock MAR day-3*Negative & & & $\begin{array}{c}-0.266^{* *} \\
(-2.10)\end{array}$ & $\begin{array}{c}-0.307^{* * *} \\
(-2.64)\end{array}$ & $\begin{array}{c}-0.313^{* * *} \\
(-2.69)\end{array}$ & $\begin{array}{c}-0.365^{* * *} \\
(-3.18)\end{array}$ & $\begin{array}{c}-0.363^{* *} \\
(-2.56)\end{array}$ & $\begin{array}{c}-0.378^{* *} \\
(-2.25)\end{array}$ \\
\hline Stock MAR day- $4 *$ Negative & & & $\begin{array}{l}-0.032 \\
(-0.26)\end{array}$ & $\begin{array}{l}-0.084 \\
(-0.63)\end{array}$ & $\begin{array}{l}-0.090 \\
(-0.68)\end{array}$ & $\begin{array}{l}-0.177 \\
(-1.35)\end{array}$ & $\begin{array}{l}-0.350^{*} \\
(-1.84)\end{array}$ & $\begin{array}{c}-0.370^{*} \\
(-1.93)\end{array}$ \\
\hline Stock MAR days $[-9,-5] *$ Negative & & & $-0.227^{* * *}$ & $-0.255^{* * *}$ & $-0.256 * * *$ & $-0.285 * * *$ & $-0.346 * * *$ & $-0.366^{* * *}$ \\
\hline
\end{tabular}




\begin{tabular}{|c|c|c|c|c|c|c|c|c|}
\hline & & & $(-2.78)$ & $(-2.92)$ & $(-2.95)$ & $(-3.31)$ & $(-2.73)$ & $(-3.51)$ \\
\hline \multirow[t]{2}{*}{ Stock MAR days[-19,-10]*Negative } & & & 0.009 & -0.010 & -0.014 & -0.036 & -0.058 & -0.026 \\
\hline & & & $(0.13)$ & $(-0.16)$ & $(-0.23)$ & $(-0.59)$ & $(-0.62)$ & $(-0.28)$ \\
\hline \multirow[t]{2}{*}{ Stock MAR days[-39,-20]* Negative } & & & -0.027 & -0.036 & -0.036 & -0.041 & -0.015 & -0.021 \\
\hline & & & $(-0.50)$ & $(-0.86)$ & $(-0.86)$ & $(-1.02)$ & $(-0.28)$ & $(-0.27)$ \\
\hline \multirow[t]{2}{*}{ Stock MAR days[-59,-40]* Negative } & & & $0.132 * *$ & $0.106^{* * *}$ & $0.104^{* * *}$ & $0.092^{* *}$ & 0.090 & 0.086 \\
\hline & & & $(2.49)$ & $(2.68)$ & $(2.61)$ & $(2.28)$ & $(1.55)$ & $(1.18)$ \\
\hline \multirow[t]{2}{*}{ Stock MAR days[-119,-60]*Negative } & & & 0.009 & -0.008 & -0.012 & -0.008 & -0.012 & -0.019 \\
\hline & & & $(0.26)$ & $(-0.30)$ & $(-0.43)$ & $(-0.30)$ & $(-0.36)$ & $(-0.37)$ \\
\hline \multirow[t]{2}{*}{ Stock MAR days[-179,-120]*Negative } & & & 0.025 & 0.029 & 0.029 & $0.043^{*}$ & 0.041 & 0.031 \\
\hline & & & $(0.69)$ & $(1.09)$ & $(1.09)$ & $(1.65)$ & $(1.19)$ & $(0.74)$ \\
\hline \multirow[t]{2}{*}{ Stock MAR days[-239,-180]*Negative } & & & 0.019 & 0.027 & 0.026 & 0.053 & $0.070 *$ & 0.049 \\
\hline & & & $(0.42)$ & $(0.81)$ & $(0.80)$ & $(1.57)$ & $(1.73)$ & $(1.05)$ \\
\hline \multirow[t]{2}{*}{ Log of total trading } & & & & $0.066^{* * *}$ & $0.066^{* * *}$ & $0.080 * * *$ & $0.106 * * *$ & 0.048 \\
\hline & & & & $(5.26)$ & $(5.23)$ & $(8.41)$ & $(11.26)$ & $(0.45)$ \\
\hline \multirow[t]{2}{*}{ Mean of Inv. Diversification Index } & & & & $-0.320 * * *$ & $-0.320 * * *$ & $-0.332 * * *$ & $-0.398 * * *$ & 0.500 \\
\hline & & & & $(-6.75)$ & $(-6.79)$ & $(-8.28)$ & $(-8.15)$ & $(1.15)$ \\
\hline \multirow[t]{2}{*}{ Mean of Inv. Daily MAR*Positive } & & & & & $-0.167 * * *$ & $-0.167 * * *$ & $-0.141^{* * *}$ & $-0.174^{*}$ \\
\hline & & & & & $(-4.26)$ & $(-3.98)$ & $(-3.46)$ & $(-1.94)$ \\
\hline \multirow[t]{2}{*}{ Mean of Inv. Daily MAR*Negative } & & & & & 0.020 & 0.029 & 0.002 & -0.090 \\
\hline & & & & & $(0.85)$ & $(1.06)$ & $(0.02)$ & $(-0.91)$ \\
\hline \multirow[t]{2}{*}{ Log of the mean of the stock account value } & & & & & & $-0.048 * * *$ & $-0.026 * * *$ & 0.034 \\
\hline & & & & & & $(-4.68)$ & $(-3.29)$ & $(0.65)$ \\
\hline \multirow[t]{2}{*}{ Account's age } & & & & & & -0.004 & $-0.016 * *$ & -0.038 \\
\hline & & & & & & $(-0.83)$ & $(-2.38)$ & $(-1.20)$ \\
\hline Gender (1=Male) & & & & & & & $(-1.02)$ & $(0.35)$ \\
\hline \multirow[t]{2}{*}{ Log of investor's age } & & & & & & & 0.038 & -0.398 \\
\hline & & & & & & & $(1.04)$ & $(-1.35)$ \\
\hline \multirow[t]{2}{*}{ Married dummy } & & & & & & & 0.009 & 0.215 \\
\hline & & & & & & & $(0.41)$ & $(1.36)$ \\
\hline \multicolumn{9}{|l|}{ Occupation: } \\
\hline \multirow[t]{2}{*}{ - Manager and entrepreneur } & & & & & & & $-0.129 * * *$ & $-0.326^{*}$ \\
\hline & & & & & & & $(-3.33)$ & $(-1.93)$ \\
\hline \multirow[t]{2}{*}{ - Consultant } & & & & & & & $0.197^{* * *}$ & -0.134 \\
\hline & & & & & & & $(2.62)$ & $(-0.39)$ \\
\hline \multirow[t]{2}{*}{ - Self-employed } & & & & & & & 0.039 & 0.181 \\
\hline & & & & & & & $(0.75)$ & $(0.56)$ \\
\hline - Other & & & & & & & $-0.053^{*}$ & -0.048 \\
\hline & & & & & & & $(-1.75)$ & $(-0.19)$ \\
\hline Investor dummies & & & & & & & & yes \\
\hline Standard errors clustered by stock & yes & yes & yes & & & & & yes \\
\hline Standard errors clustered by investor & & & & yes & yes & yes & yes & \\
\hline Observations & 46,504 & 46,504 & 46,504 & 46,500 & 46,318 & 46,302 & 27,113 & 25,634 \\
\hline Pseudo R-squared & 0.0517 & 0.0561 & 0.0638 & 0.0867 & 0.0870 & 0.0994 & 0.0845 & 0.113 \\
\hline Actual Prob. & 0.290 & 0.290 & 0.290 & 0.290 & 0.291 & 0.291 & 0.335 & 0.354 \\
\hline
\end{tabular}




\section{Table 3: Preferences for repurchasing stocks previously sold for a gain/loss}

This Table shows the Proportion of Prior Winners Repurchased (PPWR) and the Proportion of Prior Losers Repurchased (PPLR) from 1-8-2003 to 31-07-2007. Panel A presents the figures aggregated across accounts and days and assumed to be independent. Panel B presents the same figures as a mean per investor and aggregated only across days. ${ }^{*}, * *$, and ${ }^{* * *}$ stand for statistical significance at $10 \%, 5 \%$, and $1 \%$, respectively.

\begin{tabular}{lrr}
\hline Panel A: at the aggregated level & 1 year & $\mathbf{1}$ quarter \\
\hline Number of Prior Winners Repurchased & 9,953 & 10,568 \\
Number of Prior Losers Repurchased & 2,897 & 2,986 \\
Number of Opportunities to Repurchase Prior Winners & 165,977 & 87,487 \\
Number of Opportunities to Repurchase Prior Losers & 73,992 & 36,047 \\
\hline Proportion of prior losers repurchased (PPLR) & 0.0392 & 0.0828 \\
Proportion of prior winners repurchased (PPWR) & 0.0600 & 0.1208 \\
PPLR-PPWR & $-0.0208 * * *$ & $-0.0380 * * *$ \\
t-statistic & $(-22.6010)$ & $(-20.8276)$ \\
\hline
\end{tabular}

Panel B: at the individual level

\begin{tabular}{|c|c|c|c|c|}
\hline Mean of Prior Winners Repurchased by investor & 15.312 & & 14.262 & \\
\hline Mean of Prior Losers Repurchased by investor & 4.457 & & 4.030 & \\
\hline Mean of Opportunities to Repurchase Prior Winners by investor & 255.266 & & 118.009 & \\
\hline Mean of Opportunities to Repurchase Prior Losers by investor & 112.829 & & 48.126 & \\
\hline Mean of the Proportion of Prior Losers Repurchased ( $\overline{\text { PPLR }})$ & 0.1597 & & 0.1980 & \\
\hline Mean of the Proportion of Prior Winners Repurchased ( $\overline{\text { PPWR }})$ & 0.3049 & & 0.4018 & \\
\hline$\overline{\mathrm{PPLR}}-\overline{\mathrm{PPWR}}$ & -0.1452 & $* * *$ & -0.2038 & $* * *$ \\
\hline t-statistic & $(-110.4337)$ & & $(-104.7371)$ & \\
\hline
\end{tabular}

\section{Table 4: Preferences for repurchasing stocks up/down since being sold}

This Table shows the Proportion of stocks up since being sold that were repurchased (PSUSSR) and the Proportion of stocks down since being sold that were repurchased (PSDSSR) from 1-8-2003 to 31-07-2007. Panel A presents the figures aggregated across accounts and days and assumed to be independent. Panel B presents the same figures as a mean per investor and aggregated only across days. ${ }^{*}, * *$, and $* * *$ stand for statistical significance at $10 \%, 5 \%$, and $1 \%$, respectively.

\begin{tabular}{|c|c|c|c|c|}
\hline Panel A: at the aggregated level & 1 year & & 1 quarter & \\
\hline Number of Stocks up since being sold that were repurchased & 6,428 & & 6,164 & \\
\hline Number of Stocks down since being sold that were repurchased & 6,278 & & 7,139 & \\
\hline Number of Opportunities to repurchase stocks up since being sold & 146,277 & & 70,454 & \\
\hline Number of Opportunities to repurchase stocks down since being sold & 87,657 & & 50,487 & \\
\hline Proportion of stocks down since being sold that were repurchased (PSDSSR) & 0.0716 & & 0.1414 & \\
\hline Proportion of stocks up since being sold that were repurchased (PSUSSR) & 0.0439 & & 0.0875 & \\
\hline PSDSSR-PSUSSR & 0.0277 & $* * *$ & 0.0539 & $* * *$ \\
\hline t-statistic & $(27.0639)$ & & $(28.6630)$ & \\
\hline \multicolumn{5}{|l|}{ Panel B: at the individual level } \\
\hline Mean of stocks up since being sold that were repurchased by investor & 9.904 & & 8.364 & \\
\hline Mean of stocks down since being sold that were repurchased by investor & 9.673 & & 9.687 & \\
\hline Mean of opportunities to repurchase stocks up since being sold by investor & 224.468 & & 94.855 & \\
\hline Mean of opportunities to repurchase stocks down since being sold by investor & 134.838 & & 68.392 & \\
\hline $\begin{array}{l}\text { Mean of the proportion of stocks down since being sold that were repurchased } \\
\text { ( } \overline{\text { PSDSSR }}\end{array}$ & 0.3164 & & 0.4189 & \\
\hline 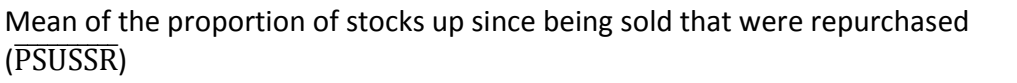 & 0.2106 & & 0.2751 & \\
\hline$\overline{\mathrm{PSDSSR}}-\overline{\mathrm{PSUSSR}}$ & 0.1058 & $* * *$ & 0.1439 & $* * *$ \\
\hline t-statistic & $(82.6477)$ & & (77.1315) & \\
\hline
\end{tabular}


Table 5: Interaction effects: Preferences for repurchasing past winners/losers and down/up since sold

This Table shows separately the Proportion of stocks up since being sold that were repurchased (PSUSSR) and the Proportion of stocks down since being sold that were repurchased (PSDSSR) for prior winner repurchased and for prior losers repurchased, from 1-8-2003 to 31-07-2007. The observations are aggregated across accounts and days and are assumed as being independent. Panel A presents the figures for Prior Winners Repurchased, while Panel B presents the figures for Prior Losers Repurchased. ${ }^{* * *}$, and $* * *$ stand for statistical significance at $10 \%, 5 \%$, and $1 \%$, respectively.

\begin{tabular}{|c|c|c|c|c|}
\hline Panel A: Prior Winners Repurchased & 1 year & & 1 quarter & \\
\hline Number of stocks up since being sold that were repurchased & 4,742 & & 4,595 & \\
\hline Number of stocks down since being sold that were repurchased & 4,917 & & 5,604 & \\
\hline Number of opportunities to repurchase stocks up since being sold & 102,894 & & 49,836 & \\
\hline Number of opportunities to repurchase stocks down since being sold & 55,794 & & 34,125 & \\
\hline Proportion of stocks down since being sold that were repurchased (PSDSSR) & 0.0881 & & 0.1642 & \\
\hline Proportion of stocks up since being sold that were repurchased (PSUSSR) & 0.0461 & & 0.0922 & \\
\hline PSDSSR-PSUSSR & 0.0420 & $* * *$ & 0.0720 & $* * *$ \\
\hline t-statistic & $(30.7637)$ & & $(30.1606)$ & \\
\hline \multicolumn{5}{|l|}{ Panel B: Prior Losers Repurchased } \\
\hline Number of stocks up since being sold that were repurchased & 1,529 & & 1,417 & \\
\hline Number of stocks down since being sold that were repurchased & 1,252 & & 1,425 & \\
\hline Number of opportunities to repurchase stocks up since being sold & 39,645 & & 18,756 & \\
\hline Number of opportunities to repurchase stocks down since being sold & 29,249 & & 15,079 & \\
\hline Proportion of stocks down since being sold that were repurchased (PSDSSR) & 0.0428 & & 0.0945 & \\
\hline Proportion of stocks up since being sold that were repurchased (PSUSSR) & 0.0386 & & 0.0755 & \\
\hline PSDSSR-PSUSSR & 0.0042 & $* * *$ & 0.0190 & $* * *$ \\
\hline t-statistic & $(2.7725)$ & & $(6.1823)$ & \\
\hline
\end{tabular}




\section{Table 6: Differences in the preferences regarding repurchasing behavior for groups of investors segmented based on frequency of trading and diversification}

This Table shows the difference in proportions, for groups of investors segmented by frequency of trading and diversification from 1-8-2003 to 31-07-2007. Percentiles are calculated after netting all trades for the same investor in the same day. Only investors that make repurchases (650 investors) are considered. An investor makes a repurchase when he buys a stock that he has previously owned and sold in the past 12 months. The percentile 50 in frequency of trading corresponds to 53.5 trades and percentile 75 corresponds to 139.5 trades, while percentile 50 in diversification corresponds to a mean of 2.2 stocks held and percentile 75 corresponds to 4 . Both panels show the difference between the Proportion of Prior Winners Repurchased (PPWR) and the Proportion of Prior Losers Repurchased (PPLR) and between the Proportion of stocks up since being sold that were repurchased (PSUSSR) and the Proportion of stocks down since being sold that were repurchased (PSDSSR) for bottom and top groups. Panel A tests the difference in proportions determined based in observations aggregated across accounts and days and assumed to be independent. Panel B presents the same figures determined by investor and tests the difference in means. $*, * *$, and $* * *$ stand for statistical significance at $10 \%, 5 \%$, and $1 \%$, respectively.

\begin{tabular}{|c|c|c|c|c|}
\hline \multicolumn{5}{|l|}{ Panel A: at the aggregated level (difference in proportions t-test) } \\
\hline \multirow{2}{*}{ e } & \multicolumn{2}{|c|}{ Frequency of trading } & \multicolumn{2}{|c|}{ Diversification } \\
\hline & Percentile 50 & Percentile 75 & Percentile 50 & Percentile 75 \\
\hline \multicolumn{5}{|l|}{$\begin{array}{l}\text { Differences in the preference for repurchasing past } \\
\text { winners/losers: }\end{array}$} \\
\hline $\begin{array}{l}(\text { PPLR-PPWR })_{\text {bottom }}-(\text { PPLR-PPWR })_{\text {top }} \\
\text { t-statistic }\end{array}$ & $\begin{array}{c}-0.051^{* * *} \\
(-2.933)\end{array}$ & $\begin{array}{c}-0.036 * * * \\
(-6.472)\end{array}$ & $\begin{array}{c}-0.039 * * * \\
(-7.148)\end{array}$ & $\begin{array}{c}-0.022 * * * \\
(-8.996)\end{array}$ \\
\hline \multicolumn{5}{|l|}{$\begin{array}{l}\text { Differences in the preference for repurchasing stocks that } \\
\text { increased/decreased in price after being sold: }\end{array}$} \\
\hline $\begin{array}{l}(\text { PSDSSR-PSUSSR })_{\text {bottom }}-(\text { PSDSSR-PSUSSR })_{\text {top }} \\
\text { t-statistic }\end{array}$ & $\begin{array}{l}0.106 * * * \\
(6.461)\end{array}$ & $\begin{array}{c}0.047^{* * *} \\
(8.055)\end{array}$ & $\begin{array}{c}0.025^{* * *} \\
(4.190)\end{array}$ & $\begin{array}{c}0.013 * * * \\
(4.873) \\
\end{array}$ \\
\hline \multicolumn{5}{|l|}{ Panel B: at the individual level (difference in means t-test) } \\
\hline \multicolumn{5}{|l|}{$\begin{array}{l}\text { Differences in the preference for repurchasing past } \\
\text { winners/losers: }\end{array}$} \\
\hline $\begin{array}{l}\overline{(P P L R}-\mathrm{PPWR})_{\text {bottom }}-\overline{(\mathrm{PPLR}-\mathrm{PPWR})}_{\text {top }} \\
\text { t-statistic }\end{array}$ & $\begin{array}{l}-0.256 * * * \\
(-7.7669)\end{array}$ & $\begin{array}{c}-0.195 * * * \\
(-5.0123)\end{array}$ & $\begin{array}{c}-0.172 * * * \\
(-5.0968) \\
\end{array}$ & $\begin{array}{c}-0.159 * * * \\
(-4.0622)\end{array}$ \\
\hline \multicolumn{5}{|l|}{$\begin{array}{l}\text { Differences in the preference for repurchasing stocks that } \\
\text { increased/decreased in price after being sold: }\end{array}$} \\
\hline $\begin{array}{l}\overline{(P P W D S S R}-\mathrm{PPWDSSR})_{\text {bottom }}-\overline{(\mathrm{PPWDSSR}-\mathrm{PPWDSSR})}_{\text {top }} \\
\text { t-statistic }\end{array}$ & $\begin{array}{c}0.013 \\
(0.378)\end{array}$ & $\begin{array}{l}0.063^{* *} \\
(1.556)\end{array}$ & $\begin{array}{c}-0.039 \\
(-1.111)\end{array}$ & $\begin{array}{c}0.001 \\
(0.029)\end{array}$ \\
\hline
\end{tabular}




\section{Table 7: Determinants of the propensity to repurchase (versus potential repurchases)}

This Table reports the results of the probit regressions that estimate the propensity of a repurchase versus potential repurchases. The values in the table are marginal effects. The sample is for the period from 1-8-2003 to 31-07-2007. The dependent variable is a dummy that equals 1 for repurchase and 0 for potential repurchase. The variables generated by interaction with "Positive" and "Negative" dummies are reported in absolute values. Independent variables are described in Appendix I. Every equation considers investor dummies. Robust z-stats clustered by stock are shown in parenthesis. ${ }^{*}, * *$, and $* * *$ stand for statistical significance at $10 \%, 5 \%$, and $1 \%$, respectively.

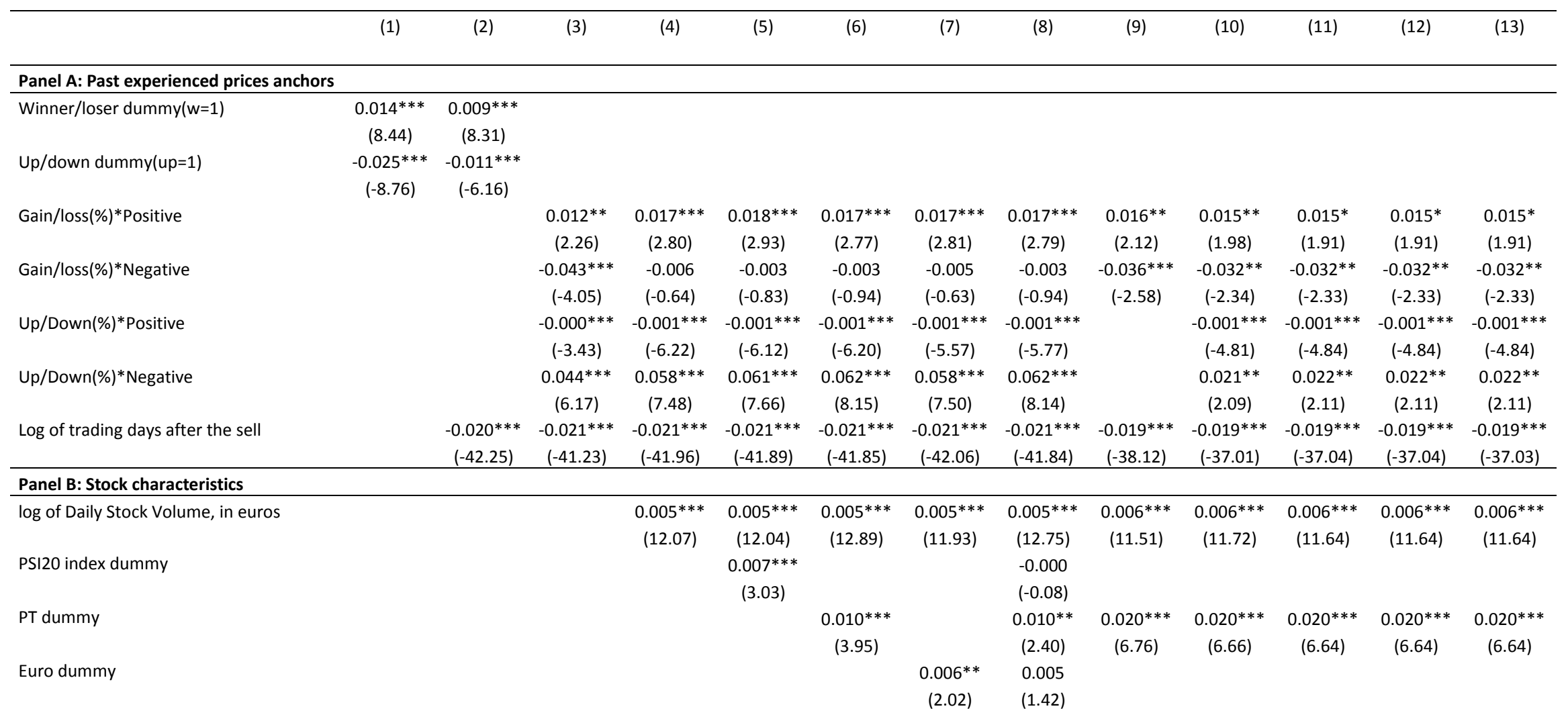




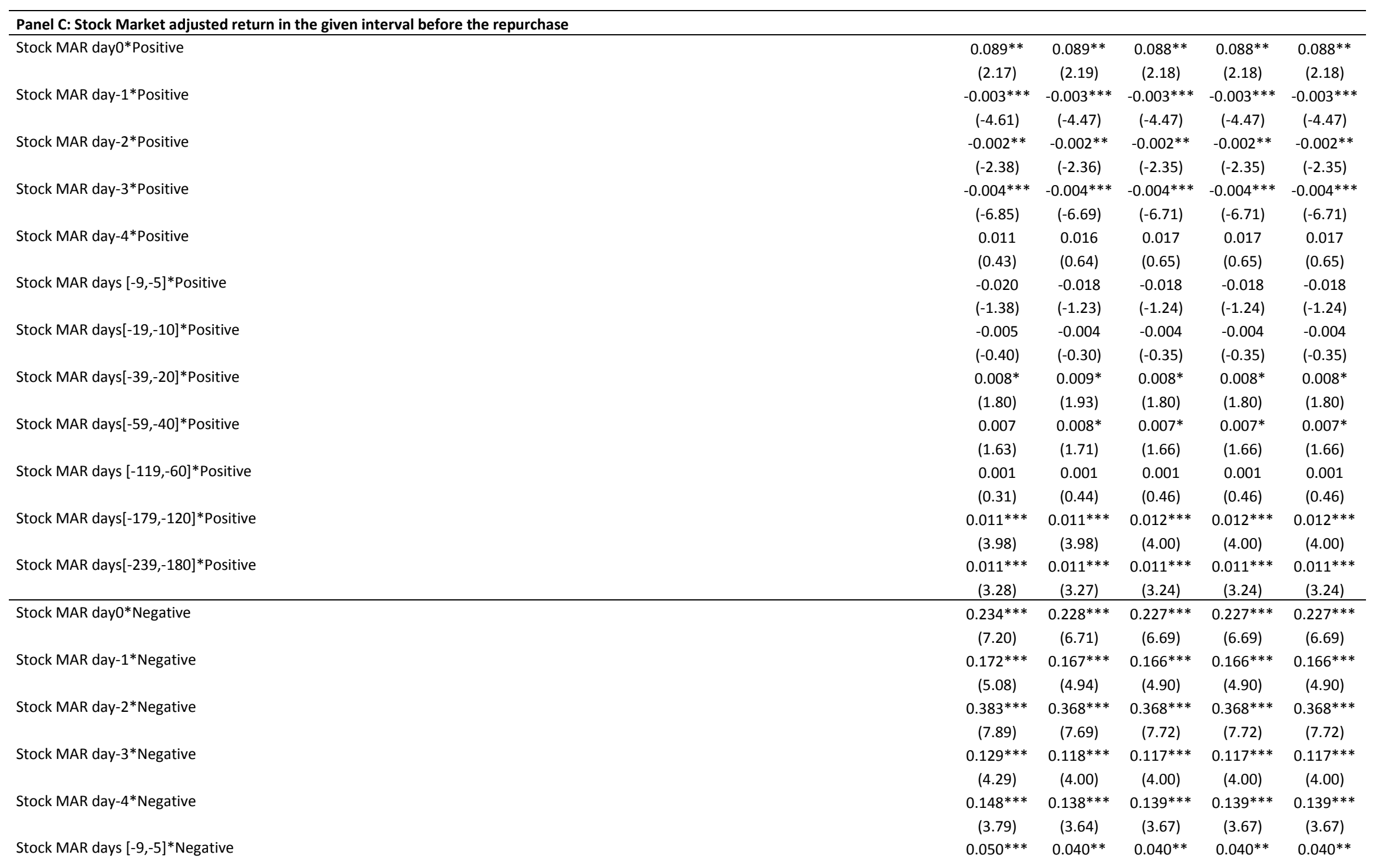




\begin{tabular}{|c|c|c|c|c|c|c|c|c|c|c|c|c|c|}
\hline & & & & & & & & & (3.20) & (2.46) & (2.44) & (2.44) & (2.44) \\
\hline Stock MAR days[-19,-10]*Negative & & & & & & & & & $\begin{array}{c}0.032 * * * \\
(2.70)\end{array}$ & $\begin{array}{c}0.024^{* *} \\
(2.02)\end{array}$ & $\begin{array}{c}0.024^{* *} \\
(2.03)\end{array}$ & $\begin{array}{c}0.024^{* *} \\
(2.03)\end{array}$ & $\begin{array}{c}0.024^{* *} \\
(2.03)\end{array}$ \\
\hline Stock MAR days[-39,-20]*Negative & & & & & & & & & $\begin{array}{c}0.026^{* * *} \\
(3.13)\end{array}$ & $\begin{array}{c}0.021^{* * *} \\
(2.60)\end{array}$ & $\begin{array}{c}0.021^{* * *} \\
(2.64)\end{array}$ & $\begin{array}{c}0.021^{* * *} \\
(2.64)\end{array}$ & $\begin{array}{c}0.021^{* * *} \\
(2.64)\end{array}$ \\
\hline Stock MAR days[-59,-40]*Negative & & & & & & & & & $\begin{array}{c}0.024^{* * *} \\
(2.72)\end{array}$ & $\begin{array}{c}0.021^{* *} \\
(2.42)\end{array}$ & $\begin{array}{c}0.021^{* *} \\
(2.41)\end{array}$ & $\begin{array}{c}0.021^{* *} \\
(2.41)\end{array}$ & $\begin{array}{c}0.021^{* *} \\
(2.41)\end{array}$ \\
\hline Stock MAR days[-119,-60]*Negative & & & & & & & & & $\begin{array}{l}0.008 \\
(1.31)\end{array}$ & $\begin{array}{l}0.006 \\
(0.98)\end{array}$ & $\begin{array}{l}0.006 \\
(0.99)\end{array}$ & $\begin{array}{l}0.006 \\
(0.99)\end{array}$ & $\begin{array}{l}0.006 \\
(0.99)\end{array}$ \\
\hline Stock MAR days[-179,-120]*Negative & & & & & & & & & $\begin{array}{l}0.007 \\
(0.89)\end{array}$ & $\begin{array}{l}0.006 \\
(0.74)\end{array}$ & $\begin{array}{l}0.006 \\
(0.81)\end{array}$ & $\begin{array}{l}0.006 \\
(0.81)\end{array}$ & $\begin{array}{l}0.006 \\
(0.80)\end{array}$ \\
\hline Stock MAR days[-239,-180]* Negative & & & & & & & & & $\begin{array}{l}0.008 \\
(0.92) \\
\end{array}$ & $\begin{array}{l}0.006 \\
(0.74) \\
\end{array}$ & $\begin{array}{l}0.007 \\
(0.79) \\
\end{array}$ & $\begin{array}{l}0.007 \\
(0.79) \\
\end{array}$ & $\begin{array}{l}0.007 \\
(0.79) \\
\end{array}$ \\
\hline \multicolumn{14}{|l|}{ Panel D: Investor account characteristics } \\
\hline Log of total trading & & & & & & & & & & $\begin{array}{c}-0.154^{* * *} \\
(-10.40)\end{array}$ & $\begin{array}{c}-0.158 * * * \\
(-10.73)\end{array}$ & $\begin{array}{c}-0.158^{* * *} \\
(-10.72)\end{array}$ & $\begin{array}{c}-0.229 * * * \\
(-13.91)\end{array}$ \\
\hline Daily Diversification Index & & & & & & & & & & & $\begin{array}{c}0.020^{* * *} \\
(5.09)\end{array}$ & $\begin{array}{c}0.020^{* * *} \\
(5.09)\end{array}$ & $\begin{array}{c}0.020^{* * *} \\
(5.09)\end{array}$ \\
\hline Mean of Inv. Daily MAR*Positive & & & & & & & & & & & & $\begin{array}{c}0.094^{* * *} \\
(5.01)\end{array}$ & $\begin{array}{c}0.074^{* * *} \\
(4.99)\end{array}$ \\
\hline Mean of Inv. Daily MAR*Negative & & & & & & & & & & & & $\begin{array}{c}0.077^{* * *} \\
(3.77)\end{array}$ & $\begin{array}{c}0.043^{* *} \\
(2.49)\end{array}$ \\
\hline Log of the mean of stock account & & & & & & & & & & & & & -0.007 \\
\hline value & & & & & & & & & & & & & $(-0.54)$ \\
\hline Log of the mean of total account & & & & & & & & & & & & & 0.014 \\
\hline value & & & & & & & & & & & & & $(0.91)$ \\
\hline Investor dummies & yes & yes & yes & yes & yes & yes & yes & yes & yes & yes & yes & yes & yes \\
\hline Standard errors clustered by stock & yes & yes & yes & yes & yes & yes & yes & yes & yes & yes & yes & yes & yes \\
\hline Observations & 251,193 & 251,193 & 251,193 & 240,255 & 240,255 & 240,255 & 240,255 & 240,255 & 192,005 & 192,005 & 192,005 & 192,005 & 192,003 \\
\hline Pseudo R-squared & 0.0952 & 0.192 & 0.190 & 0.198 & 0.199 & 0.199 & 0.198 & 0.199 & 0.212 & 0.213 & 0.214 & 0.214 & 0.214 \\
\hline Actual Prob. & 0.0525 & 0.0525 & 0.0525 & 0.0544 & 0.0544 & 0.0544 & 0.0544 & 0.0544 & 0.0568 & 0.0568 & 0.0568 & 0.0568 & 0.0568 \\
\hline
\end{tabular}




\section{Most Recent Working Paper}

NIPE WP Leal, Cristiana Cerqueira, Armada, Manuel Rocha e Loureiro, Gilberto , "Individual

22/2013 Investors Repurchasing Behavior: Preference for Stocks Previously Owned, 2013

NIPE WP Loureiro, Gilberto e Alvaro G. Taboada, "Equity Offerings Abroad and the adoption of IFRS: A 21/2013 test of the Capital Markets Liability of Foreignness", 2013

NIPE WP Loureiro, Gilberto e Alvaro G. Taboada, "Do Improvements in the Information Environment

20/2013 Affect Real Investment Decisions?", 2013

NIPE WP Bogas, Patrícia e Natália Barbosa, "High-Growth Firms: What is the Impact of Region-Specific

19/2013 Characteristics?", 2013

NIPE WP Portela, Miguel e Paul Schweinzer, “The Parental Co-Immunization Hypothesis”, 2013

$18 / 2013$

NIPE WP Martins, Susana e Francisco José Veiga, "Government size, composition of public expenditure,

$17 / 2013$ and economic development", 2013

NIPE WP Bastos, Paulo e Odd Rune Straume, "Preschool education in Brazil: Does public supply crowd

16/2013 out private enrollment?", 2013

NIPE WP Martins, Rodrigo e Francisco José Veiga, "Does voter turnout affect the votes for the incumbent

15/2013 government?", 2013

NIPE WP Aguiar-Conraria, Luís, Pedro C. Magalhães e Christoph A. Vanberg, "Experimental evidence

$14 / 2013$ that quorum rules discourage turnout and promote election boycotts", 2013

NIPE WP Silva, José Ferreira, J. Cadima Ribeiro, “As Assimetrias Regionais em Portugal: análise da

13/2013 convergência versus divergência ao nível dos municípios", 2013

NIPE WP Faria, Ana Paula, Natália Barbosa e Vasco Eiriz, "Firms' innovation across regions: an

$12 / 2013$ exploratory study", 2013

NIPE WP Veiga, Francisco José, “Instituições, Estabilidade Política e Desempenho Económico

11/2013 Implicações para Portugal”, 2013

NIPE WP Barbosa, Natália, Ana Paula Faria e Vasco Eiriz, "Industry- and firm-specific factors of

10/2013 innovation novelty", 2013

NIPE WP Castro, Vítor e Megumi Kubota, "Duration dependence and change-points in the likelihood of

09/2013 credit booms ending", 2013

NIPE WP Monteiro, Natália Pimenta e Geoff Stewart "Scale, Scope and Survival: A Comparison of

08/2013 Cooperative and Capitalist Modes of Production", 2013

NIPE WP Esteves, Rosa-Branca e Joana Resende, "Competitive Targeted Advertising with Price

07/2013 Discrimination", 2013

NIPE WP Barbosa, Natália, Maria Helena Guimarães e Ana Paula Faria, "Single Market non-

06/2013 compliance: how relevant is the institutional setting?", 2013

NIPE WP Lommerud, Kjell Erik, Odd Rune Straume e Steinar Vagstad, "Mommy tracks and public

05/2013 policy: On self-fulfilling prophecies and gender gaps in promotion", 2013

NIPE WP $\quad$ Brekke, Kurt R., Luigi Siciliani e Odd Rune Straume, "Hospital Mergers: A Spatial

04/2013 Competition Approach", 2013

NIPE WP Faria, Ana Paula e Natália Barbosa, “Does venture capital really foster innovation?”, 2013

$03 / 2013$

NIPE WP Esteves, Rosa Branca, “Customer Poaching with Retention Strategies”, 2013

$02 / 2013$

NIPE WP

$01 / 2013$

NIPE WP

27/2012

NIPE WP

26/2012

NIPE WP

25/2012

Aguiar-Conraria, Luís, Teresa Maria Rodrigues e Maria Joana Soares, "Oil Shocks and the Euro as an Optimum Currency Area", 2013

Ricardo M. Sousa, "The Effects of Monetary Policy in a Small Open Economy: The Case of

Portugal" 2012

NIPE WP Jawadi, F. e Ricardo M. Sousa, "Consumption and Wealth in the US, the UK and the Euro Area:

$24 / 2012$

Sushanta K. Mallick e Ricardo M. Sousa, "Is Technology Factor-Neutral? Evidence from the US

Manufacturing Sector" 2012 